\author{
Marcin Stonawski \\ Cracow University of Economics, Cracow, Poland \\ International Institute for Applied Systems Analysis (IIASA), \\ World Population Program, Laxenburg, Austria \\ stonawsm@uek.krakow.pl \\ Michaela Potančoková \\ Wittgenstein Centre for Demography and Global Human Capital \\ (IIASA, VID/OAW, WU), Vienna Institute of \\ Demography, Vienna, Austria \\ michaela.potancokova@oeaw.ac.at \\ Vegard Skirbekk \\ Columbia Aging Centre, Columbia University, U.S.A. \\ vegard.skirbekk@fhi.no

\section{DEMOGRAPHIC PROJECTIONS BY RELIGION AND EDUCATION IN INDIA ${ }^{1}$}

\title{
INTRODUCTION
}

In the past years demographic methods have been applied to global and national estimates and projections of religion, both globally and for individual nations across the world (PEW 2011, Kaufmann et al. 2012, Goujon et al. 2007, Stonawski et al. 2014, 2015). By factoring in religion-specific fertility differentials and changes in age structure, one can more accurately forecast changes in the country's religious composition than is possible through a simple extrapolation. However, members of religious groups tend to differ in numerous other socio-economic characteristics and observed fertility differentials may be influenced for example more by variation in education than a result of belonging to a particular religious group. Education has been consistently found to influence fertility (Bongaarts 2003, Jejeebhoy 1995, Fuchs and Goujon 2014) as well as both child and adult mortality (Kravdal 2004, Albouy and Lequien

${ }^{1}$ We would like to thank Markus Speringer for creating the maps and Matthew Cantele for the editing. We acknowledge support by a Starting Grant of the European Research Council, Grant Agreement 241003-COHORT. 
2009, Subramanian et al. 2006). The relation between education and fertility is negative, and stronger than for other measures of socio-economic development, including income or occupational status (Skirbekk 2008). In this paper we argue that incorporating education as an additional dimension of the multi-state projection model can further improve projections of country's future religious composition.

We illustrate the relevance of education for projecting changes of religious landscape in the case of India. This religiously diverse country may become the most populous nation on earth in the coming 15 years (UN 2013), but its longer term demographic development remains highly uncertain. On the one hand, it has experienced rapid economic growth, high levels of urbanization, increases in literacy and strong fertility decline. On the other hand, in spite of rapid societal change a large share of India's population remains rural and conservative regarding cultural norms and customs, with levels of formal schooling increasing relatively slowly compared to other middle income countries (Dyson et al. 2005, Nachane 2011). Religion is central in the identity and daily lives of many Indians - only $0.1 \%$ of the Indian population in the 2001 census did not state a religion. This is highly relevant in the context of India as religion is an important determinant of demographic behaviour for many (Joseph 2013, Kumar 2012).

India is also a country of great social inequality and regional disparities. Gaps in education and differences in family size are significant across the subcontinent's plentiful religious groups. Hindus are by far the most numerous and amount to $80 \%$ of India's population in 2001. However, Muslims and some other smaller religious have higher fertility than Hindus. One can expect that India's religious composition will be changing due to the distinctly different demographic behaviour of various religions. Will India become a more religiously diverse country by mid- $21^{\text {st }}$ century? In this paper we focus on this question. We look at the possible future religious compositions of India's population depending on demographic and educational change. We investigate several alternative scenarios of future change in India's religious composition derived from the significant educational differentials we find in the country.

In the next section we elaborate on the relevance of including an educational dimension for modelling religious change and explain the multistate model we apply to model demographic, educational and religious change simultaneously. Before moving to the projection results, we look at religious and educational disparities across Indian states. We conclude with presenting projections of the religious composition in India by education until 2050.

\section{RELIGIOSITY, EDUCATION AND FERTILITY}

For as long as it has been measured, education has been found to generally be negatively associated with fertility (in contrast to other indicators such as income) (Akmam 2002, Abou-Gamrah 1982, Abbasi-Shavazi et al. 2009, Skirbekk 2008). 
Today, education is one of the most important drivers of differential fertility - longer education tends to imply later marriage, later onset of childbearing, and a smaller family size - with stronger effects in poorer countries. Further, religious differentials in developing countries have been explained to a large extent by variation in education levels (Heaton 2011).

Contraceptive use differs by religious groups, and it has for a long period (Bhat and Zavier 2005). Among married women, Hindus saw their current use of contraception remain lower, for example contraceptive use rose from $14 \%$ to $49 \%$ in the years 1970-1999, while for Muslims it increased from $9 \%$ to $37 \%$ over the same period. Differences in education and other socioeconomic traits can explain much of the differences observed in contraception and fertility between religious groups (Joseph 2013, Rocca et al. 2013). Yet, religion can have independent effects on fertility (Rocca et al. 2013).

Education can also explain differences in demographic behaviour by religious groups. Indian education levels differ significantly between religious groups (Jeffery and Jeffery 1997). In Dhanbad district, Jharkhand, data collected through a household survey suggest that the number of children is greater among Muslims than Hindus, but at a higher educational status the difference narrows considerably. Thus, education seems to have a fertility-converging effect, reducing the fertility differences between Hindus and Muslims (Siddiqui and Jamal 2012).

Education has also been found to affect religiosity. In Turkey, compulsory school reforms implemented in 1998 - individuals born after a specific date had to go to school for 8 years while those born earlier could drop out after 5 - led to lowered religiosity in terms of wearing a headscarf, attending Qur'anic courses and regular praying (Gulesci and Meyersson 2012). The marginal effect of an extra year of schooling in Canada has been found to relate to a 4 percent drop in religiosity (Hungerman 2011). Education and religion are both important individual and societal characteristics. Further, they may also be important for determining fertility levels and group-specific as well as overall population growth. India is home to numerous religious traditions. Hinduism and Buddhism, two of the largest world religions were born in India as well as many other religions that find their roots there (including Jainism and Sikhism). India has the largest community of Hindus and the third largest community of Muslims globally (PEW 2012). In $2001^{2}$, there were $81.7 \%$ of Hindus, $11.6 \%$ of Muslims, $2.9 \%$ of Christians, and $3.9 \%$ of others among the Indian population at age 25 and older ${ }^{3}$.

2 Population composition by religion and/or education from the 2011 census was not available by 2015 .

3 We choose to focus on individuals aged 25 and above. This is done for the following reasons: a) most religious (and other types of attitudinal or value-orientation related change) takes place at younger ages, typically around the teens or early twenties (Skirbekk et al. 2010, Ryder 1980, Goujon et al. 2007); b) by avoiding focusing on children and early adults we also avoid controversies surrounding whether children should automatically be assigned the religion of their parents or one should wait until early adulthood. c) as we are focused on education, we would like to present data for an age where most 
In spite of increases in literacy and education, the Indian population is still lagging behind China and the "tiger economies" of South-East Asia. Mean years of schooling (MYS) among population at age 25 and above equalled 7.9 years in 2001. Christians are the best-educated religious group with $12.2 \%$ of people with post-secondary education and $35.2 \%$ with secondary education (Table 1). Thus, their share of the total post-secondary educated population is disproportionately larger than their representation within the general population. The proportion of Christians among post-secondary educated was $4.8 \%$ in 2001 but if the shares had corresponded to the proportional distribution of the religious groups, the Christian share would have been $3.9 \%$. Among people with no education a mere $1.6 \%$ were Christians (Figure 1). The lowest educated group is Muslims; only $3.8 \%$ had post-secondary education and $17.3 \%$ attained secondary level. Muslims $(11.6 \%$ of the total population) were overrepresented among those with no formal education (13.1\%) and among those with primary education (12.7\%). Among Hindus $7.4 \%$ were post-secondary educated and $22.6 \%$ secondary educated. School enrolment rates suggest that religion-specific differences are likely to persist in the future. In 2005 the General Enrolment Rate (GER) in higher Indian education was $16.7 \%$ for Christians, $11.9 \%$ for Hindus and a mere $6.8 \%$ for Muslims (University Grants Commission 2008). Gender gaps in education are strongly pronounced as well, in particular among Muslims and Hindus.

Figure 1. Religious composition of population 25 and older by education in India in 2001, in \%

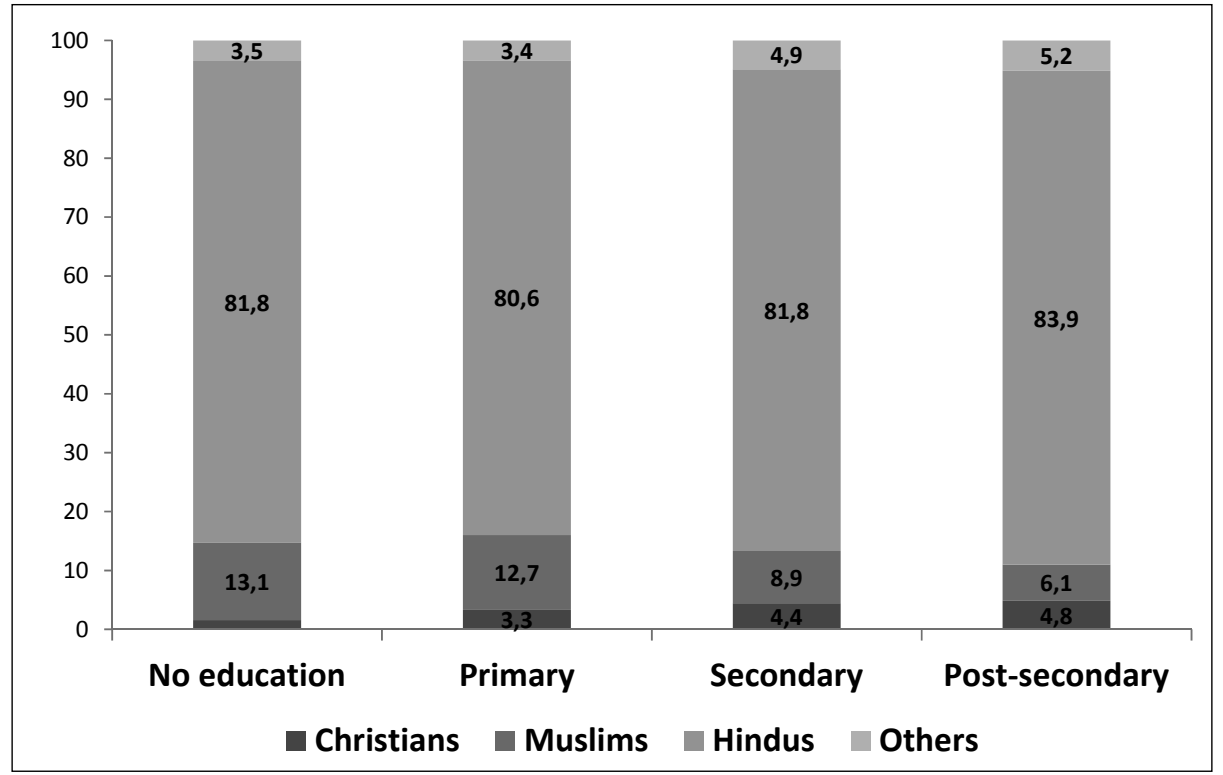

Source: own calculations based on Indian census 2001.

have completed their education - we therefore choose the age of 25 as many still are in their education in their early twenties. 


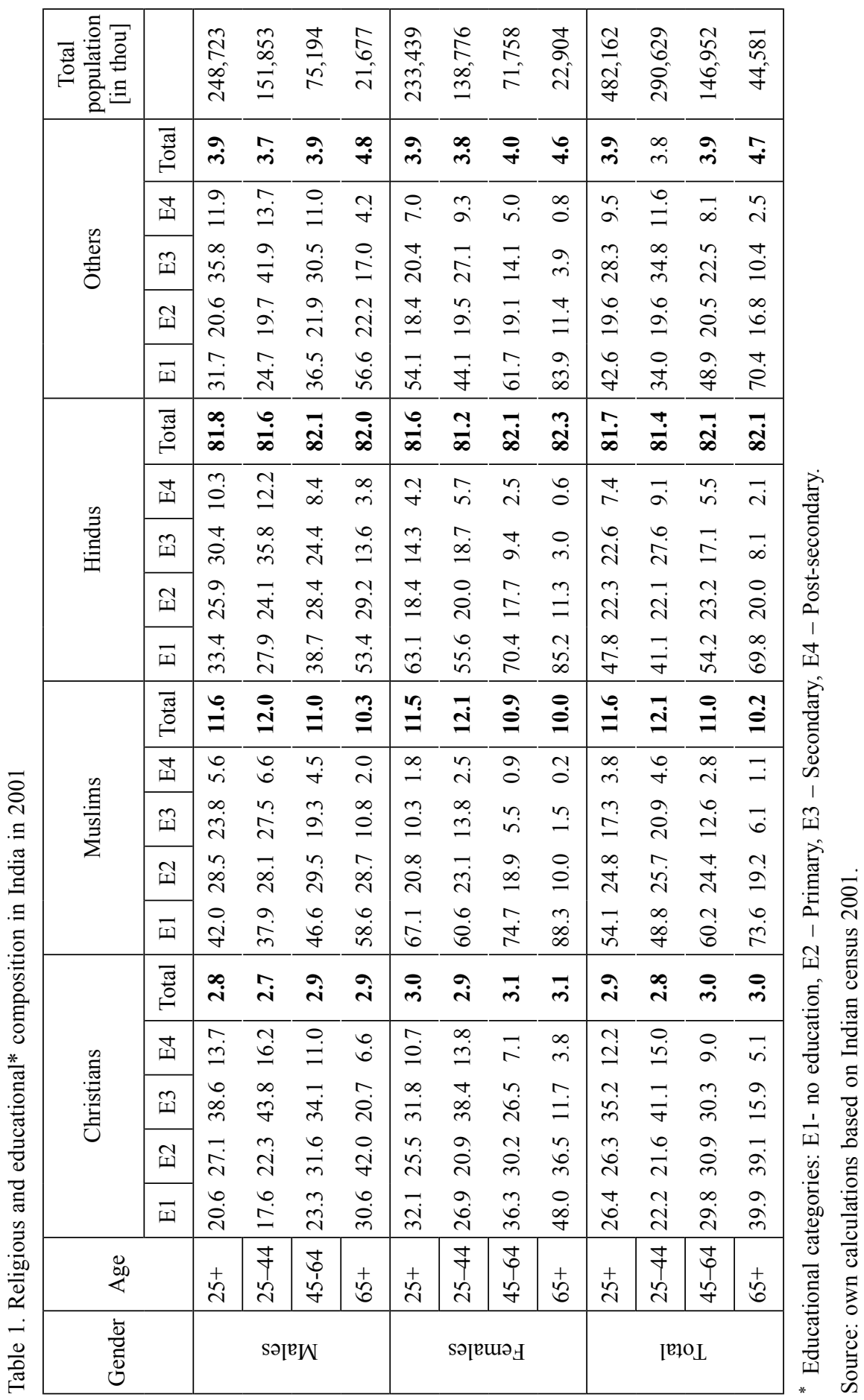


In a country the size of India one can expect significant regional variation in socio-cultural characteristics. This turns out to be true for both religion and education. Educational differences arise due to different state policies. We can expect higher educational attainments in the southern compared to the less developed northern states (Suryanarayana et al. 2011).

Hindus are a clear majority in most large Indian states while north-eastern, northern states and Kerala are religiously diverse (Figure 2). In five states we find more than $90 \%$ of Hindus (Himachal Pradesh [HP: 95.4\%], Chhattisgarh [CT: 94.7\%], Orissa [OR: 94.4\%], Dadra and Nagar Haveli [DN: 93.5\%] and Madhya Pradesh [MP: 91.1\%]). The states and union territories with the lowest shares are Nagaland (NL: 7.7\%), Lakshadweep (LD: 3.7\%) and Mizoram (MZ: 3.6\%). As expected, we find the highest share of uneducated Hindus in Bihar (BR: 63.5\%) and a very low share of adult population with at least lower secondary education in other northern states (Uttar Pradesh, Rajasthan, Madhya Pradesh). Unsurprisingly, the states with the best-educated Hindu population (with less than 25\% uneducated among 25 year and more olds and more than $7 \%$ with post-secondary education) are Delhi (DL:

Figure 2. Proportion and educational composition of Hindu population (aged 25 and more) by region in India in $2001^{*}$

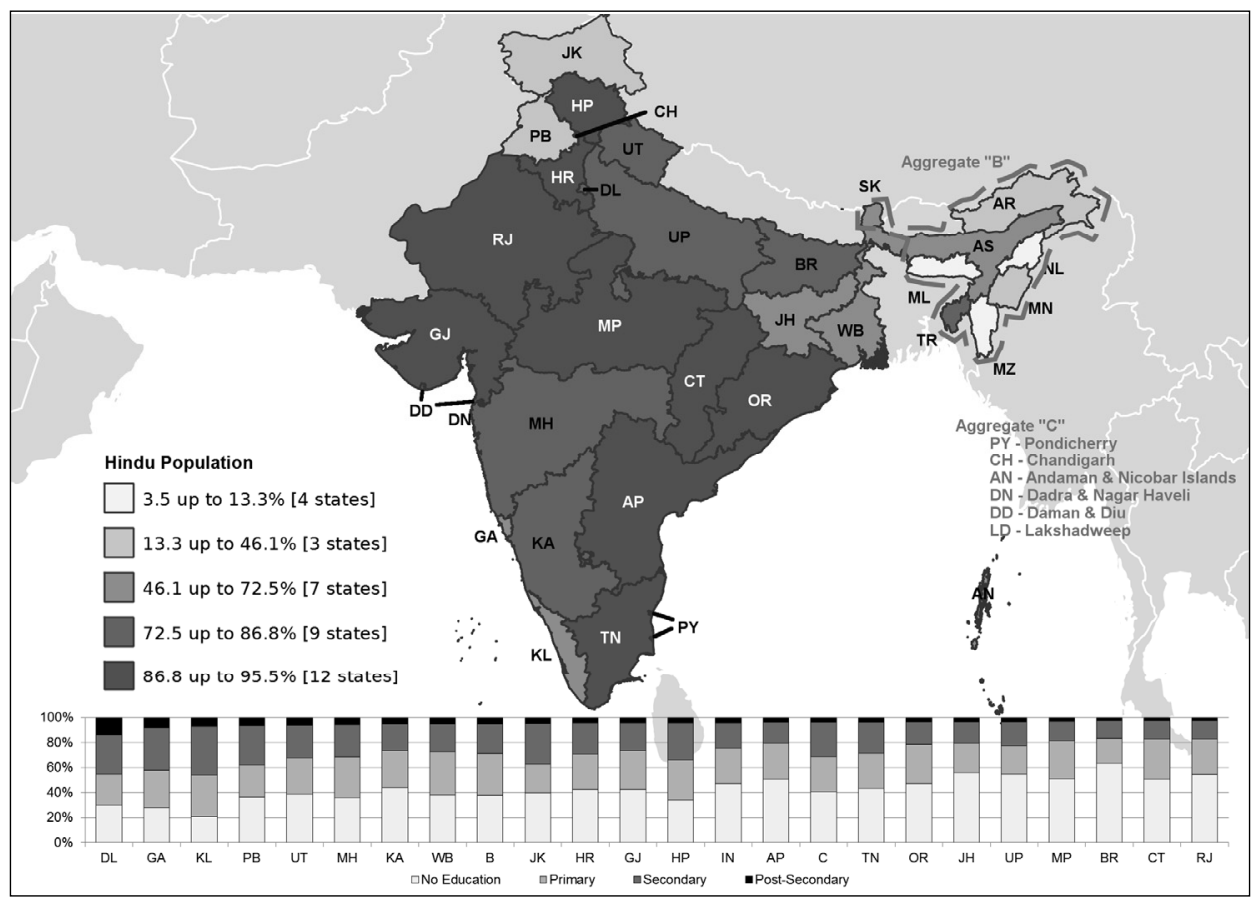

* State abbreviations are described in Appendix 2.

Source: own calculations based on Indian Census 2001, cartography prepared by Markus Speringer. 
29.6\% / 13.7\%), Goa (GA: 28.1\% / 8.4\%) and Kerala (KL: 20.5\% / 7.0\%). Further more, Kerala has the lowest share of non-educated Hindus in India. The states with less than 3\% of population with post-secondary education are Sikkim (SK: 3.0\%), Bihar (BR: 2.8\%), Chhattisgarh (2.7\%) and Rajasthan (RJ: 2.6\%).

By contrast, India's Christians are on average much better educated and a higher share of them than of any other religious group had post-secondary education. Christians in India were mainly located in the Northeastern states (here labelled as "Aggregate B") and in the South, with the highest shares in Nagaland (NL: 90.0\%), Mizoram (MZ: 87.0\%), Meghalaya (ML: 70.3\%) and Manipur (MN: 43.2\%) (Figure 3). 24 out of 35 states and union territories had less than 5\% Christian population. In 13 spatial units located in Central, Western and Northern India the share was even less than $1 \%$. Although marginal in numbers, more than $15 \%$ Christians residing in Delhi, Maharashtra and Madhya Pradesh, Haryana and Haryana attained post-secondary education (DL: $24.1 \%$, MP: $16.8 \%$, HR: 15.6\%) and more than $50 \%$ had at least secondary education. The case of Madhya Pradesh shows that minority religious groups can be surprisingly successful in terms of human capital

Figure 3. Proportion and educational composition of Christian population (aged 25 and more) by region* in India in 2001

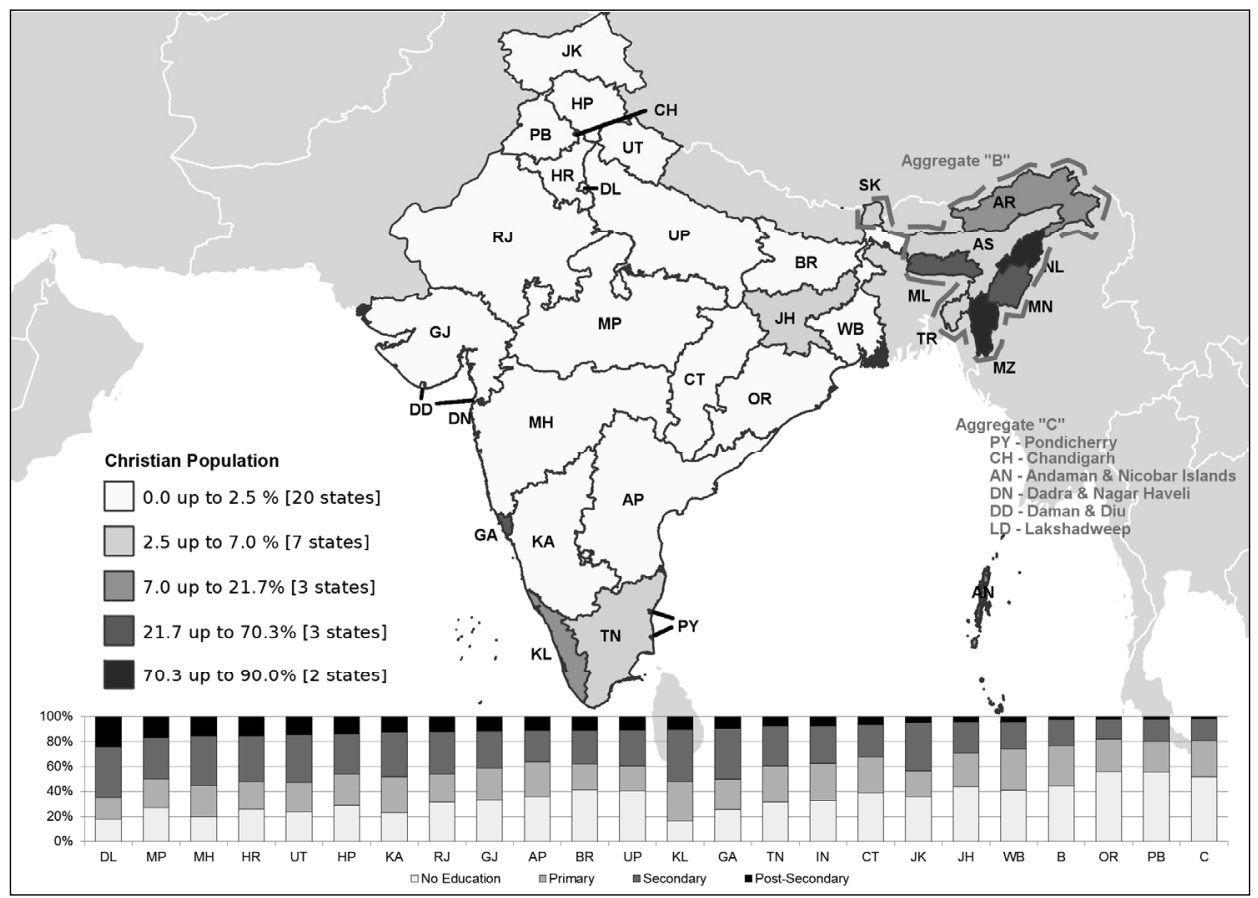

* State abbreviations are described in Appendix 2.

Source: own calculations based on Indian Census 2001, cartography prepared by Markus Speringer. 
accumulation even in contexts where members of majority religions perform poorly. However, in Northeastern states where Christians form a higher share of population than elsewhere (the B cluster in the map), they are less educated than their counterparts in other Indian states but also less educated than Hindus resident in the same states.

Muslims, India's largest religious minority group, are located nearly across the whole country. Their proportion is especially high in the Northern and Southwestern states, with the highest shares in Lakshadweep (LD: 95.5\%), Jammu and Kashmir (JK: 67.0\%), Assam (AS: 30.9\%), West Bengal (WB: 25.2\%) and Uttar Pradesh (UP: $24.7 \%$ ) (Figure 4). In general, Muslims have relatively low education and in 5 states the share of uneducated exceeds $60 \%$ of the population aged 25 and more (Bihar, Uttar Pradesh, Haryana, Jammu and Kashmir, Uttaranchal). In Kerala, where educational attainment is higher than in most other states, nearly $40 \%$ of Muslims had at least secondary education - a similar share to Kerala's Hindus. In spite of generally worse educational characteristics, Muslims are better educated than Hindus in 5 states: Arunachal Pradesh, Tamil Nadu, Madhya Pradesh, Orissa and Gujarat. In

Figure 4. Proportion and educational composition of Muslim population (aged 25 and more) by region* in India in 2001

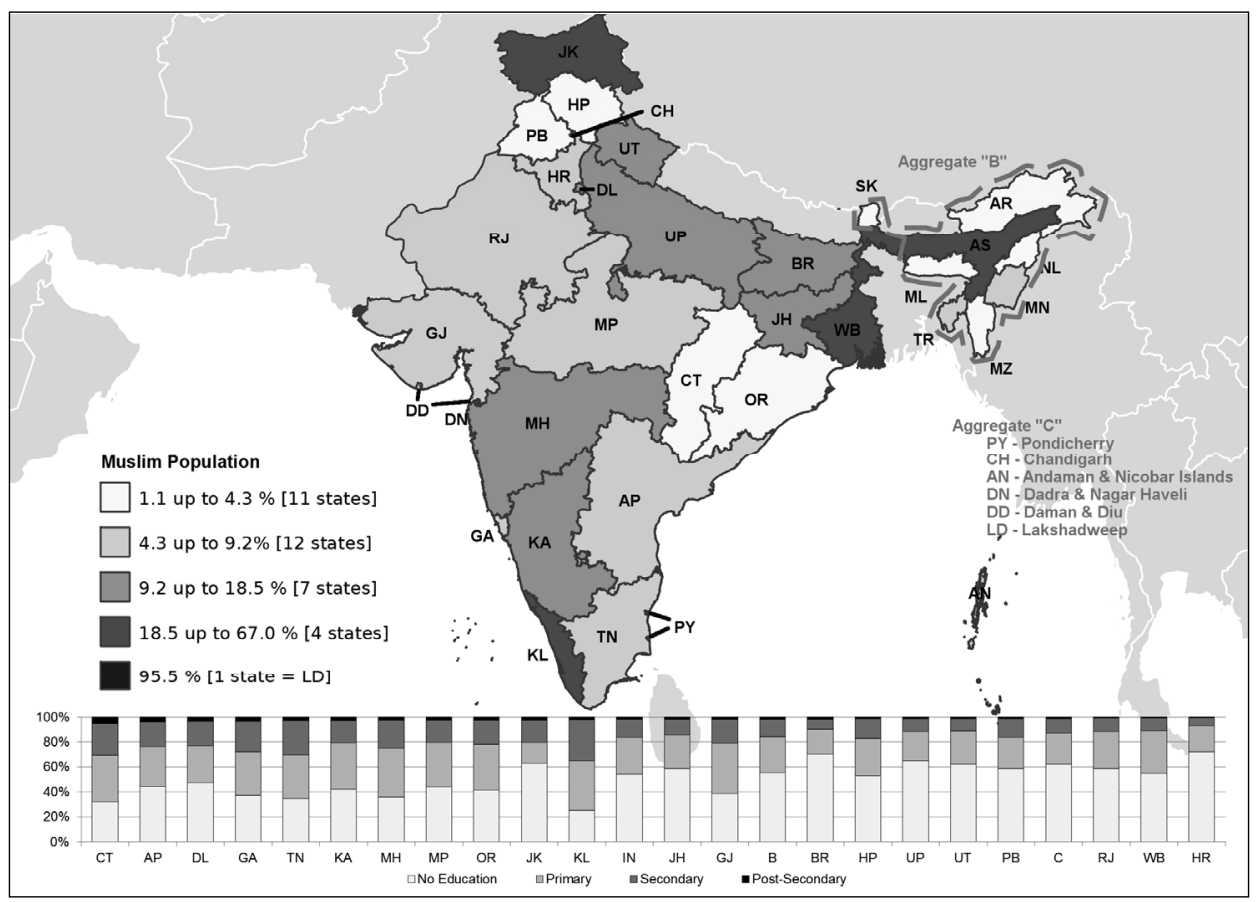

* State abbreviations are described in Appendix 2.

Source: own calculations based on Indian Census 2001, cartography prepared by Markus Speringer. 
all these states fewer Muslims than Hindus have no formal education and the share of those with primary education is higher. Except for Gujarat, the share or those with secondary education is about equal to Hindus and the share of post-secondary educated is generally lower. In Gujarat the educational advantage of Muslims in primary education is not translated into advantage at secondary level.

The share of confessors of other religions is the highest in the Northeastern states Arunachal Pradesh (AR: 31.6\%), Jharkhand (JH: 13.1\%), Meghalaya (ML: 11.8\%) and Manipur (MN: 10.9\%) (Figure 5). The share of other religious groups is high in states with a large Buddhist population while in the north-east and east indigenous groups with local folk religions comprise a large part of the residual group. The spatially small Daman and Diu (DD: 24.0\%), Delhi (DL: 23.7\%), Chandigarh (CH: $15.6 \%)$ and Pondicherry (PY: $15.5 \%$ ) have the highest share of post-secondary educated population in the category of other religions. The states with lowest share of the highest educational category tend to be located in Central India, like Madhya Pradesh (MP: 0.7\%), Chhattisgarh (CT: 0.8\%), West Bengal (WB: 0.9\%) and Jharkhand (JH: $1.0 \%)$.

Figure 5. Proportion and educational composition of confessors of other religions (aged 25 and more) in India by region* in 2001

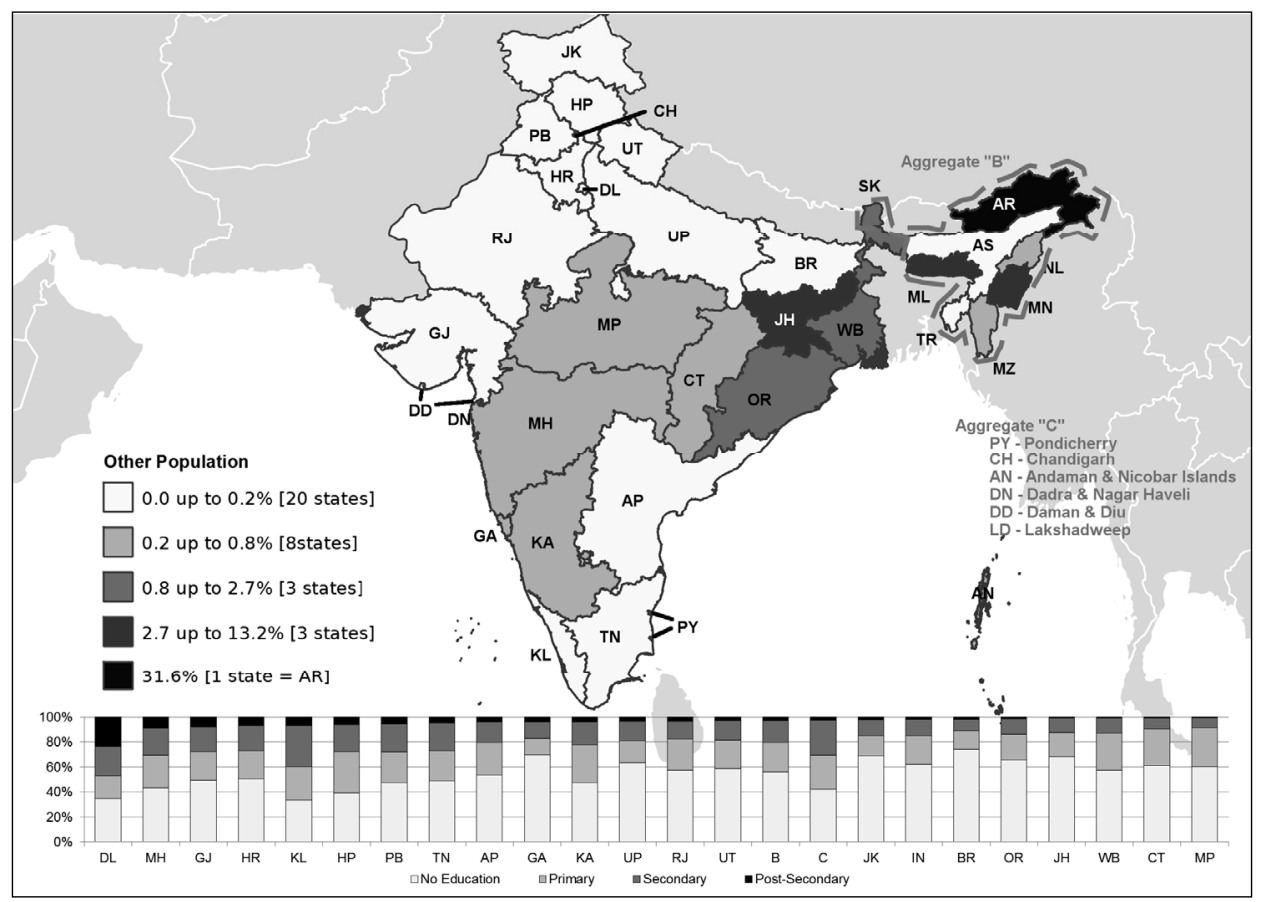

* State abbreviations are described in Appendix 2.

Source: own calculations based on Indian Census 2001, cartography prepared by Markus Speringer. 


\section{PROJECTIONS BY RELIGION AND EDUCATION}

\section{DATA AND METHODS}

In this study, we carry out multi-state population projections by religion and education in India for the period 2000-2050. Multistate projection is a demographic methodology which can be used in projections of populations disaggregated by status - individual characteristics that can change over time - such as educational attainment, marital status, or religion and level of religiosity (for more details on this method see Philipov and Rodgers 1981, Hackett et al. 2014, Rogers 1975, 1995).

First, we estimate the base population for the year 2000 by age, sex, religion, and education using the 2001 Indian census. We distinguish four religious groups: Christians, Muslims, Hindus and Others, and four educational groups: No education, Primary, Secondary and Post-secondary (Table 2).

Table 2. Recoding of educational attainment categories

\begin{tabular}{|l|c|c|}
\hline \multicolumn{1}{|c|}{ Category } & Abbreviation & ISCED 1997 level \\
\hline No education & E1 & 0 \\
\hline Primary & E2 & 1 \\
\hline Secondary & E3 & 2 and 3 \\
\hline Post-secondary & E4 & 4,5 and 6 \\
\hline
\end{tabular}

Differentials in childbearing levels and patterns by religion and education are then calculated using data from the 2005-2006 Demographic and Health Survey (DHS). Then we estimate international migration flows by age, sex, religion and education. We include mechanism of intergenerational transmission of religion between mothers and children that allows cohort effects to be included in the projection model. We also take into consideration trajectories of educational change during individual life span which are religion-specific. We do not include religious switching into the projection model because of empirical evidence suggest that changes of religious affiliation are very marginal in India.

\section{PROJECTION ASSUMPTIONS AND SCENARIOS}

Our aim is to study possible consequences of change in education and fertility on the future religious composition of India. We present four scenarios that illustrate the effect of education improvement, changing fertility differentials and stall in education and/or fertility. 
As we have argued in the previous sections, female education is a crucial determinant of fertility outcomes. However, the proportion of females with at least secondary education in India was only around $20 \%$. According to the UN, the TFR for India was 2.52010 , but fertility is much lower for better-educated females. According to DHS 2005-2006, the TFR of women with no formal education was nearly twice the rate (3.55) of those who had at least 12 years of schooling (completed upper secondary education and higher, TFR 1.80).

Fertility differentials by religion and education are pronounced. TFRs by religion and education for the baseline period for India are shown in Figure 6. Baseline fertility rates were estimated by applying the differentials by education and religion to TFR for the $2000 \mathrm{UN}$ estimates. We find the expected education gradient for all religious groups - women with no formal education have the highest fertility while highly educated the lowest. Differentials are the most pronounced for Muslims, who have the highest overall fertility ( 3.4 children), and the least pronounced for Christians, who have a lower overall TFR ( 2.3 children). Fertility rates of women with a minimum of secondary education are well below the country average for both Muslims and Hindus. Other religions are a mixed group that includes religious groups with sub-replacement fertility (Buddhists and Sikhs) as well as high-fertility groups of Folk-religionists and Jains. Fertility differentials are greatest among the less educated.

Figure 6. Total fertility rate by religion and education* in India in 2000-2005

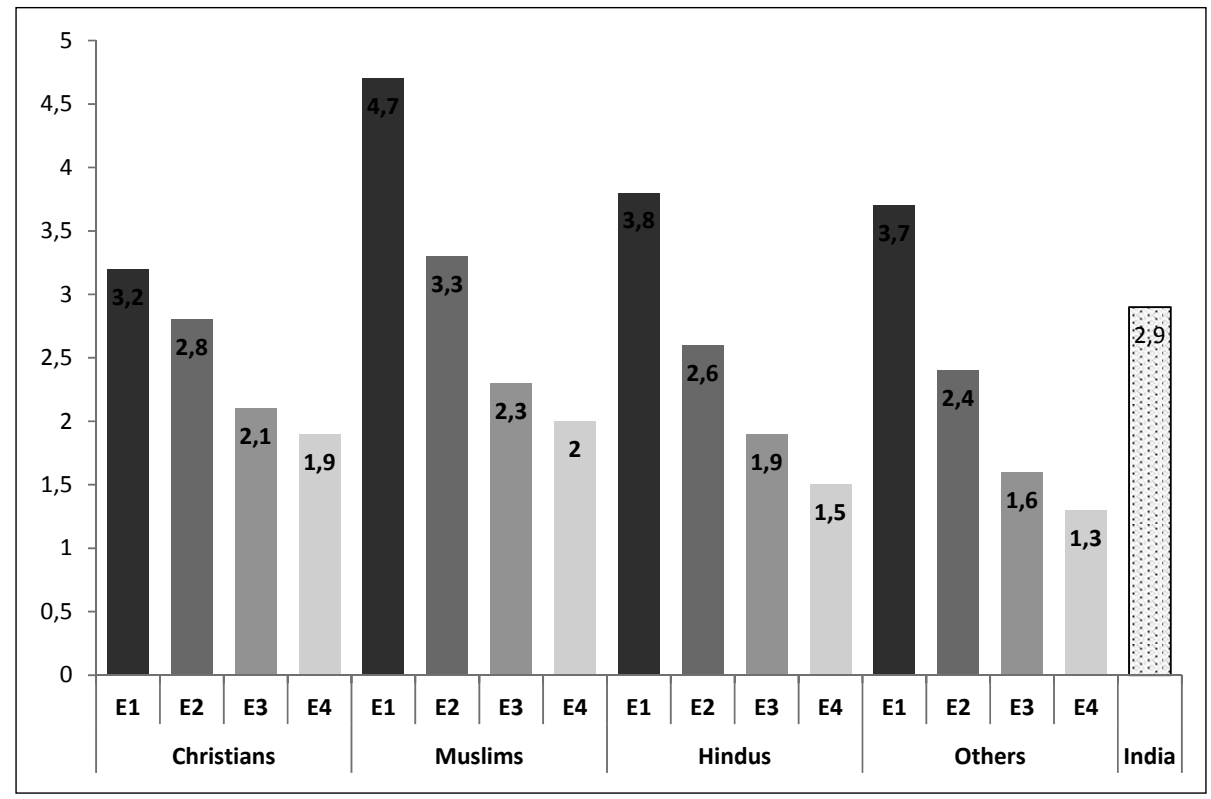

* E1 - no education, E2 - Primary education (some primary or completed primary), E3 - Secondary education (completed lower or higher secondary), E4 - Postsecondary (above upper secondary).

Source: own calculations based on DHS 2005-6 and UN 2011. 
We consider three possible trajectories of future fertility defined with respect to both absolute and relative fertility differentials across the religious and educational groups. Constant fertility $\left(F_{C}\right)$ represents the simplest scenario where TFR is "frozen" as of 2000. This means that both the relative differentials and education- and-religion-specific TFRs stay the same for the whole projection period. The constant relative differentials scenario (Fr) shows a case where overall TFR follows the UN medium scenario (UN 2011), but the relative differentials between the religious and educational groups remain (Figure 7). Finally the fertility convergence $(\mathrm{Fg})$ is the case where all fertility differentials by religion and education converge by 2060 while overall TFR of India follows the UN medium scenario (UN 2013). The assumed convergence of fertility differentials results in a fertility rebound as the convergence concerns declining TFRs for low educated, and increasing fertility for highly educated. The effect is illustrated in Figure 8 for Hindus and Muslims.

Figure 7. Total Fertility Rates by education* among Muslims and Hindus according to the constant relative differentials scenario $(F r)$

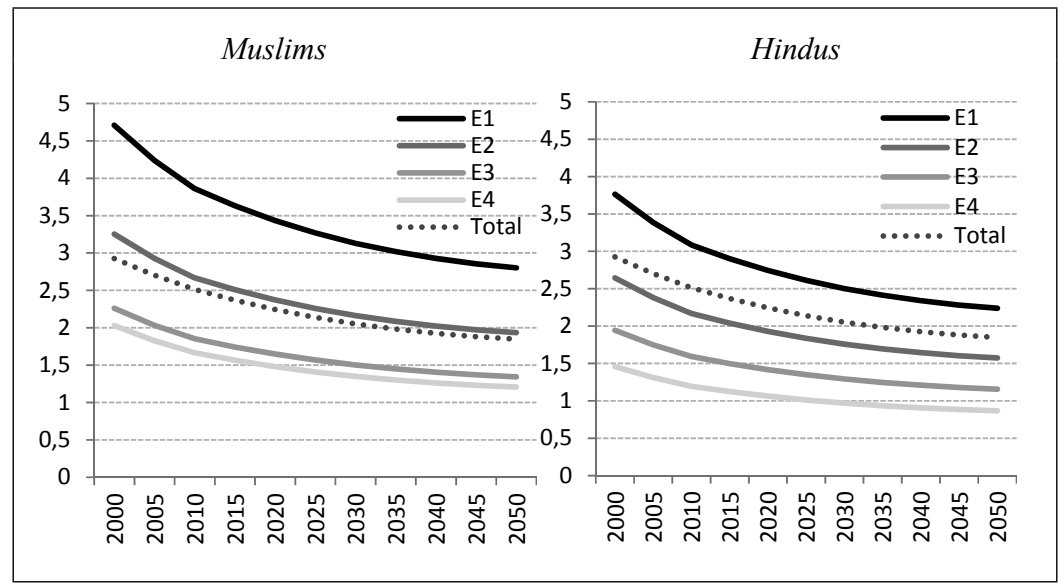

* E1 - no education, E2 - Primary education (some primary or completed primary), E3 - Secondary education (completed lower or higher secondary), E4 - Postsecondary (above upper secondary).

Source: own elaboration.

To illustrate the effect of education we choose a combination of two simple scenarios. In the rapid increase scenario $(E r)$ education rises following the educational expansion observed in South Korea in the second half in $20^{\text {th }}$ century - a country with the fastest educational expansion ever witnessed. This results in rapid education change by 2050 . The rapid increase scenario is formulated in accordance to the fast track (FR) scenario of the recently published global human capital projections (KC et al. 2014). To show the other extreme we present the constant education scenario (Ec) 
Figure 8. Total Fertility Rates by education* among Muslims and Hindus according to the convergence in fertility scenario $(\mathrm{Fg})$

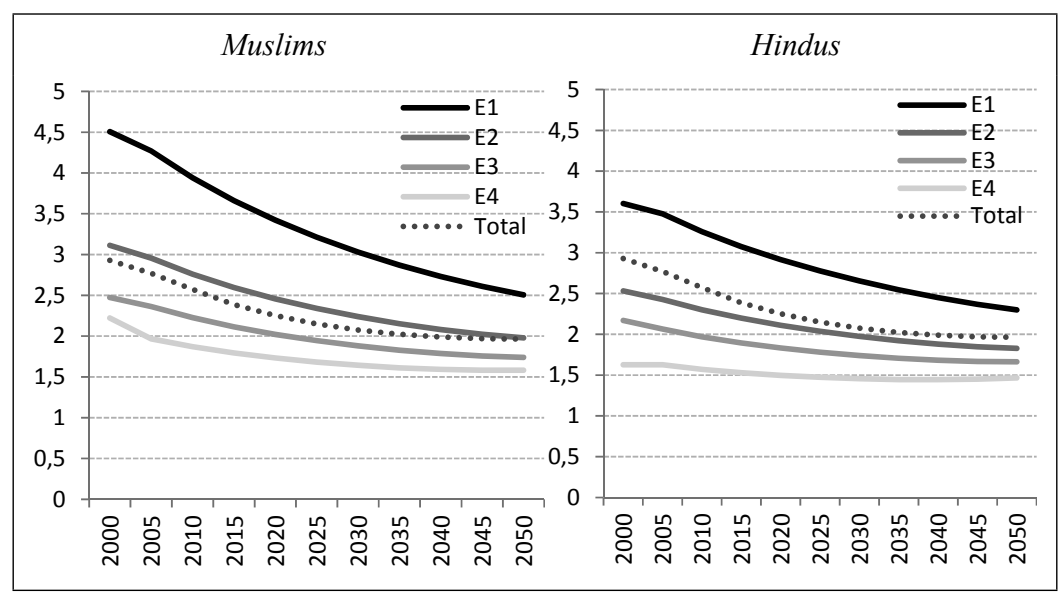

* E1 - no education, E2 - Primary education (some primary or completed primary), E3 - Secondary education (completed lower or higher secondary), E4 - Postsecondary (above upper secondary).

Source: own elaboration.

where educational enrolment does not increase beyond the levels recorded in 2001 (formulated in terms of constant enrolment rates (CER) scenario in $\mathrm{KC}$ et al. (2014). Scenarios represent two extreme trajectories and the actual educational improvements in India will fall within this range. The change in educational composition in the rapid increase scenario is shown in Figure 9.

Figure 9. Educational composition of the population aged 25 years and above in India, 2000, 2050, in \%

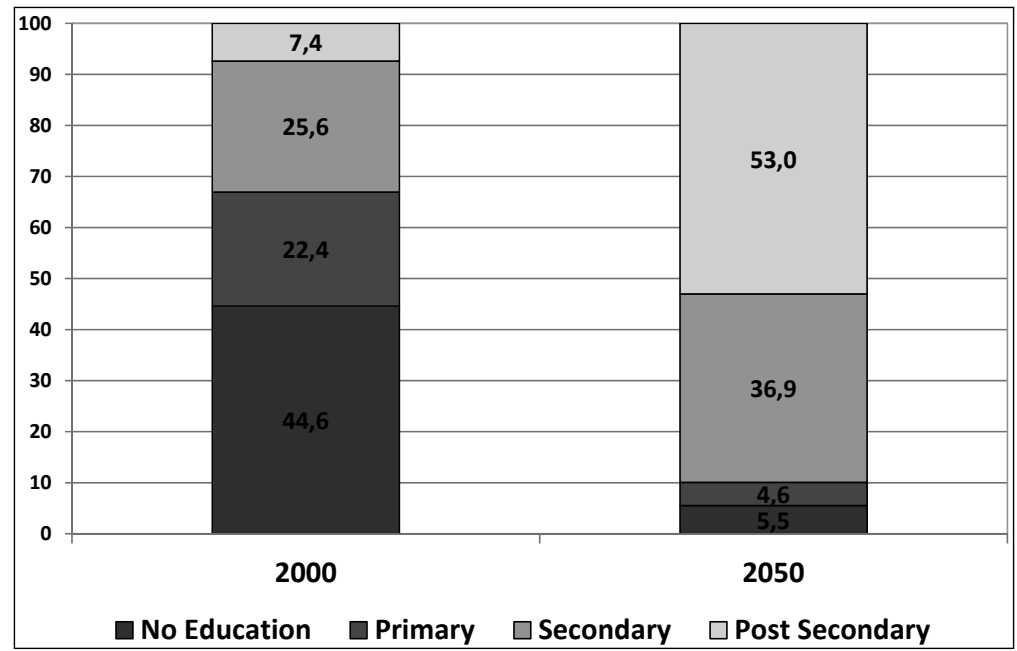

Source: own calculations. 
Because we aim to illustrate the effects of educational and fertility change, we do not include multiple migration or mortality scenarios. In our projections the netmigration follows the assumptions of the UN medium scenario (UN 2013). We use religious composition of in-migration and out-migration developed in the Pew-ACC Religion and Demography Study (Figure 10) (Hackett et al. 2014, Stonawski et al. 2014). We assume random selection of migrants in terms of education. Outmigration rates by age, sex, religion and education are kept constant for the entire projection period. In-migration flows by age, sex, religion and education vary in order to meet the UN net migration levels.

Figure 10. Religious composition of migrant flows (in \%)

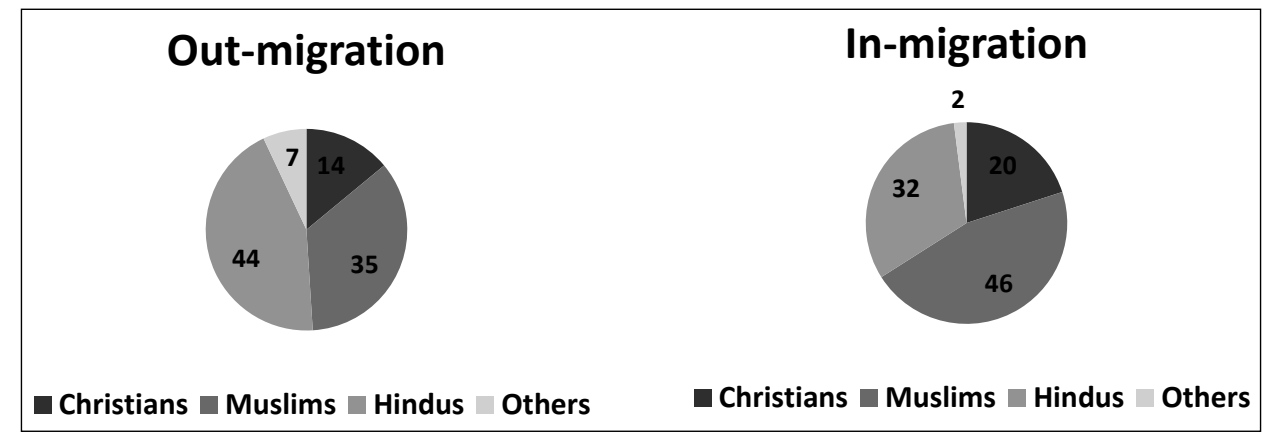

Source: own calculations.

Mortality patterns are the same for all religious groups and follow the UN medium scenario. Religious switching is marginal in India is not taken into account. Hinduism is one of few religions person can enter only by birth and the share of religiously unaffiliated is negligible. This results in fairly stable religious transmission pattern and most of the change can be captured by demographic processes. It is possible that modernisation and increasing education will bring secularisation in the future (Norris and Inglehart 2004), however, research studies on religion in India have not found a significant disaffiliation process in India (e.g. Hackett et al. 2015). We also do not find any evidence for this in our data.

The presented four scenarios are combination of the three fertility and two education scenarios:

- EcFc is a constant scenario that represents stall in fertility and education. It can be understood as a benchmark scenario and provides a point of reference to illustrate the effects of education and fertility change.

- EcFr is a persisting inequality scenario. In this possible future inequalities in education and fertility persist. Enrolment rates are constant and there is no educational expansion but compared to the constant scenario fertility decline continues. Ferti- 
lity differentials across the religious and educational groups, however, remain as of 2000.

- ErFc is an educational expansion scenario. Fertility remains constant, i.e. educational improvements do not translate into change in childbearing. It is presented to demonstrate the effect of improving education.

- $\boldsymbol{E r F g}$ is a convergence scenario that represents the most optimistic possible trajectory of rapid educational expansion that translates into behavioural change. Fertility declines as education improves and fertility differentials between religious and educational groups shrink. This development would result in diminishing inequality.

\section{CHANGING RELIGIOUS LANDSCAPE OF INDIA UNTIL 2050}

India had 1.05 billion inhabitants in 2000. In the next 50 years, its population is expected to significantly increase to at least 1.7 billion, as shown in Figure 11. In case of stalled fertility and no improvements in educational enrolment, India's population would more than double to over 2.3 billion. This trajectory is highly unlikely and illustrates that fertility decline or development in education has a very strong impact on population size. The results show that increased education makes a great difference and the educational expansion scenario $(E r F c)$ illustrates the pure effect of rapid educational expansion on population size. Just by increasing the number of highly educated women, the Indian population would grow to 1.9 instead of 2.3 billion even if education-specific TFRs remained the same as in 2000. The combination of educational expansion and fertility decline leads to even lower population size of 1.7 billion in 2050 .

Figure 11. Overall population size of India according to 4 scenarios, 2000-2050

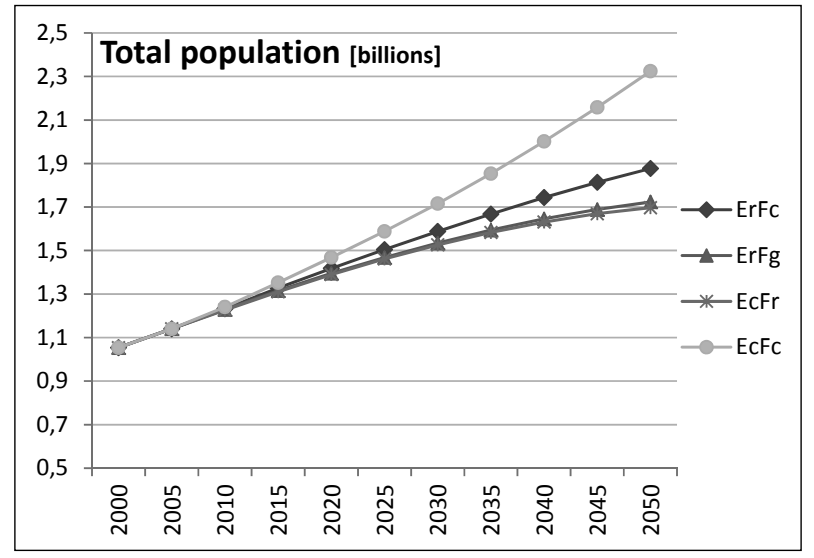

Source: own calculations. 
The combination of educational expansion and converging fertility differentials (convergence scenario, $E r F g$ ) results in population size similar to the persisting inequality scenario (with stalled educational improvements, fertility declining according to the UN medium scenario but persisting fertility differentials, $E c F r$ ) due to lower overall TFR than in the convergence scenario (Figures 7 and 8). However, these two scenarios result in very different religious compositions of Indian population by 2050 (Figure 12).

Figure 12. Projected shares of religious groups in the overall population of India according to 4 scenarios, 2000-2050

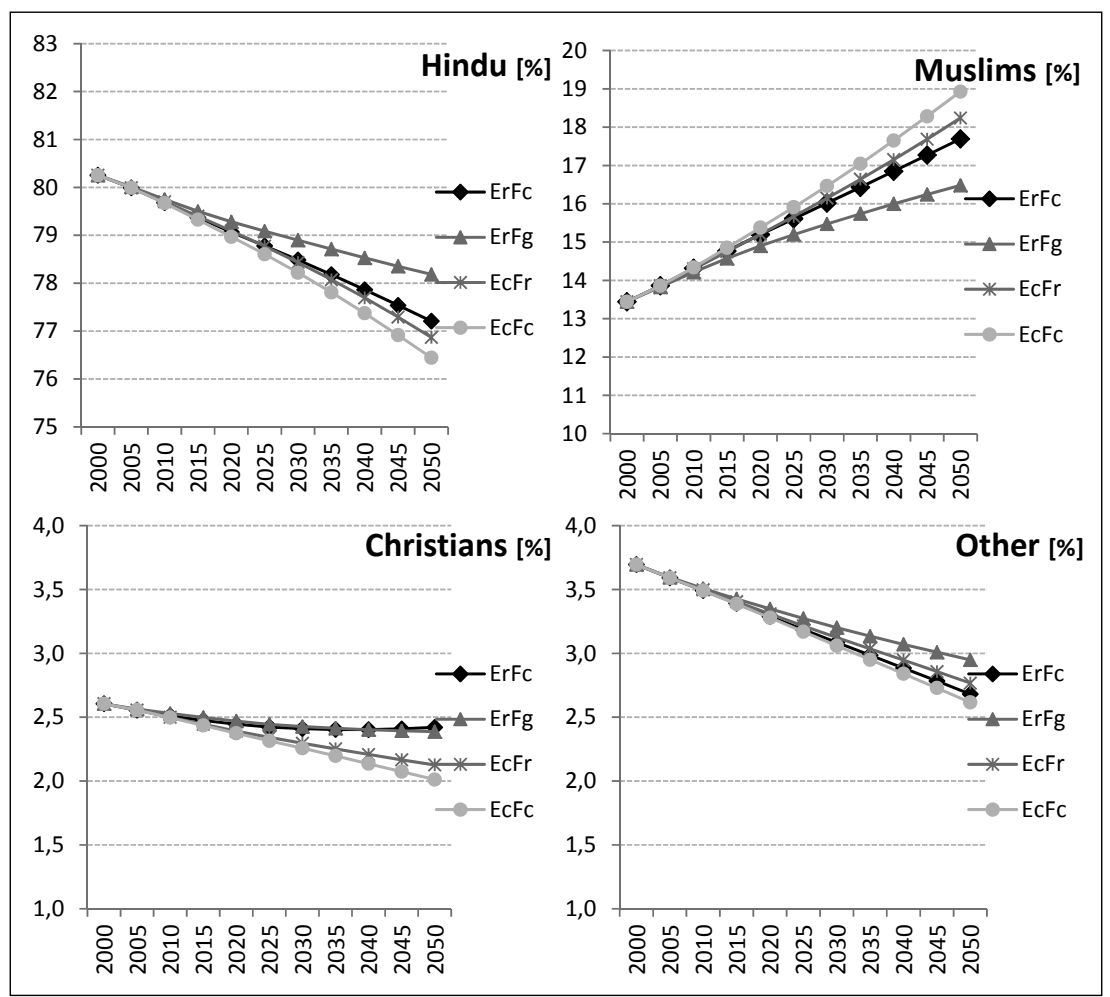

Source: own calculations.

Persisting inequality in fertility outcomes and education $(E c F r)$ would turn India into a country less dominated by Hindus. Their share on total population would decline from 80.3 in 2001 to 76.9 in 2050. Due to a larger share of less educated and higher fertility than Hindus, the share of Muslims would rise from $13.3 \%$ in 2001 to $18.2 \%$ in 2050 and the total Muslim population would more than double to 310 million (Figure 13). The share of other religious groups would decline.

The total population size would be the same should the convergence scenario $(\mathrm{ErFg})$ become the future trajectory of India's population, but Indians would most 
likely live in a more equal and prosperous country. India's economy could take the opportunity of the demographic dividend if education increased rapidly and shrinking family size allowed Hindu and Muslim families alike to invest more into the human capital of their children. As a result of education reinforcing fertility decline, and under the condition of diminishing fertility differentials, the religious landscape of India would change the least under this scenario. The share of Muslims would increase to a lesser extend to $16.5 \%$, and would still double to 284 million but the share of Hindus would decline the least by 2.1 percentage points to $78.2 \%$ by 2050 . The share of Christians would stay about the same (2.6 in 2000 compared to 2.4 in 2050 ) and the share of other religions would shrink from $3.7 \%$ to $2.9 \%$.

Figure 13. Projected size of religious groups in India according to 4 scenarios, 2000-2050

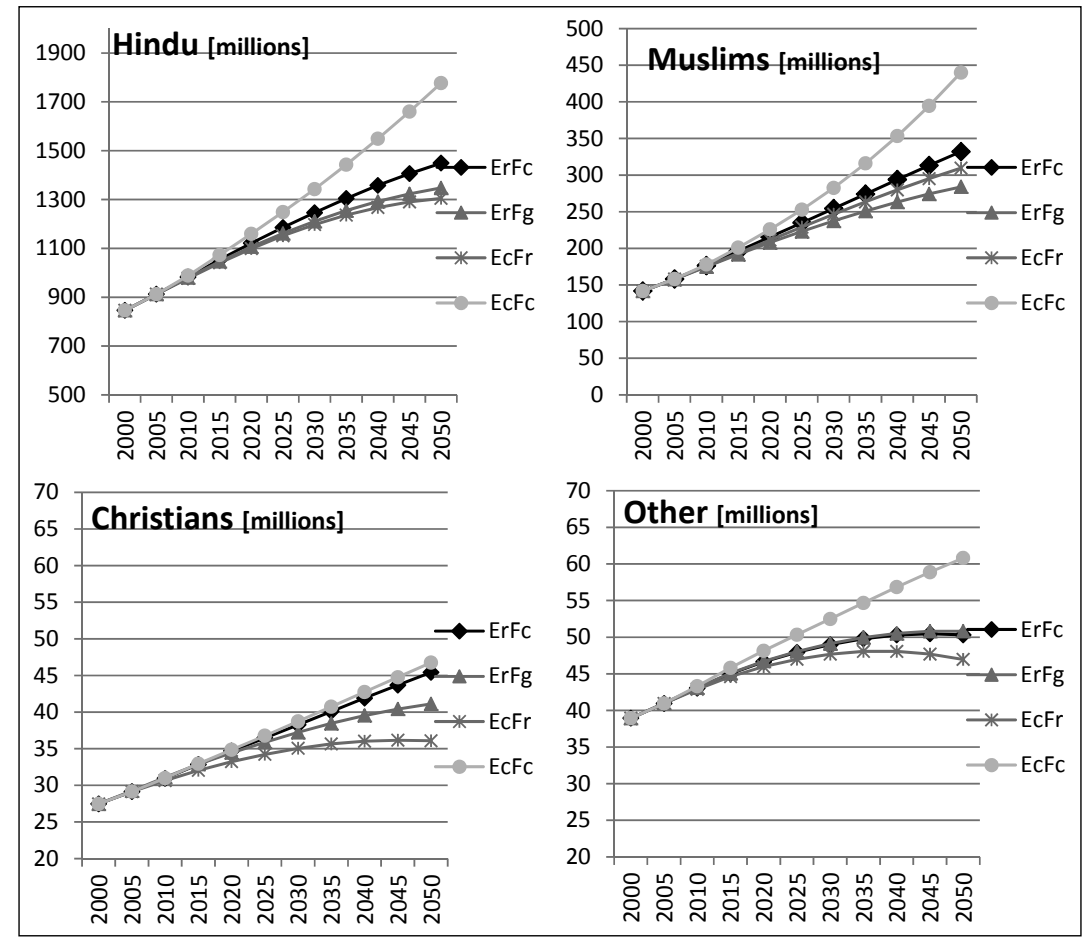

Source: own calculations.

The religious composition of India changes the most significantly under the constant scenario $(E c F c)$, which results in rapid growth of the Muslim population. This scenario illustrates the long-term effect of stalled fertility and education enrolment. In this scenario we assume TFRs and fertility differentials remain as of 2000-2005. If only education was driving the change and fertility stalled $(E r F c)$, the resulting religion-specific TFRs would be influenced only by compositional changes of the population of women in reproductive age. The educational characteristics of 
Christian women would be changing at the slowest pace because they were better educated than women of other religions. Therefore, their TFR would remain at about 2.6 children per woman until the end of the projection period. All other religious groups would experience fertility decline. Holding fertility rates by education constant, a fast increase in education would depress the fertility of Hindus from 2.83 to about replacement level of 2.16 children per woman. Muslims would experience the most rapid educational improvements because of their worst education characteristics in 2001 and, consequently, rapid fertility transition. The TFR of Muslim women would plummet from 3.76 to 2.5 children per woman. A rapid educational increase in combination with convergence of fertility differentials by 2060 would result in the narrowest differentials in fertility between the groups $(\mathrm{ErFg})$.

Overall TFR of India would decline to 2.22 children per women without any shift in fertility pattern if India were to replicate the educational expansion witnessed by South Korea $(E r F c)$. Should fertility differentials persist and education would not improve $(E c F r)$ overall Indian TFR would fall more rapidly to 1.85 children per woman in 2050 and all religious groups but Muslims would have sub-replacement fertility. Fertility decline would be less pronounced under the convergence scenario $(\mathrm{ErFg})$ and the overall fertility would stabilize at about 1.96 towards 2050. Muslims would still be the most fertile religious group.

Changes in education and fertility would influence population age structure and population ageing of the religious groups. Muslims had the youngest population in India in 2001 with mean age of nearly 24 years, while Hindus are on average at 27 years and Christians and others at 28 (Table 3 ). The constant scenario $(E c F c)$ and

Table 3. Projected population mean age by scenario, India 2000, 2025, 2050

\begin{tabular}{|cc|cccc|c|}
\hline Scenario & Year & Christians & Muslims & Hindu & Other & Total \\
\hline \multirow{3}{*}{ ErFc } & 2000 & 28.3 & 23.8 & 26.7 & 27.9 & 26.4 \\
& 2025 & 32.7 & 28.0 & 31.6 & 34.1 & 31.2 \\
& 2050 & 35.8 & 32.9 & 36.4 & 40.4 & 35.9 \\
\hline \multirow{3}{*}{ ErFg } & 2000 & 28.3 & 23.8 & 26.7 & 27.9 & 26.4 \\
& 2025 & 33.2 & 29.1 & 32.1 & 34.1 & 31.8 \\
& 2050 & 38.3 & 35.7 & 37.9 & 40.2 & 37.7 \\
\hline \multirow{3}{*}{ EcFr } & 2000 & 28.3 & 23.8 & 26.7 & 27.9 & 26.4 \\
& 2025 & 34.0 & 28.6 & 32.3 & 34.4 & 31.8 \\
& 2050 & 40.6 & 34.4 & 38.6 & 41.7 & 38.0 \\
\hline \multirow{2}{*}{ EcFc } & 2000 & 28.3 & 23.8 & 26.7 & 27.9 & 26.4 \\
& 2025 & 32.2 & 26.7 & 30.4 & 32.7 & 29.9 \\
& 2050 & 34.8 & 28.5 & 32.4 & 35.8 & 31.8 \\
\hline
\end{tabular}

Source: own calculations. 
the persisting differentials scenario $(E c F r)$ would lead to an increasing gap between the religious groups in term of population ageing. Muslims would be aging at the slowest pace and by 2050 their mean age would not exceed 36 years in any presented scenario. Educational expansion would speed up population ageing of all religious groups. The gap between Muslims and Hindus will be closing rapidly, especially under the convergence scenario $(\mathrm{ErFg})$.

\section{SUMMARY}

In sum, both education and religion have independent effects on family formation and childbearing patterns, and thereby the population growth of India's religious groups. Hence, it is important to take into account both these different dimensions, particularly when focusing on a demographically important country such as India. This study has demonstrated that a more rapid educational increase and lower fertility is likely to a) lead to slower overall population growth as well as a somewhat older population, but also b) decrease variation in the growth rate of different religious groups. There is likely to be a gradual shift in the religious composition of the Indian population.

Considering religion and education collectively has the potential to significantly improve our ability to understand social processes more accurately. Educational attainment is added to the religious projections because it can affect fertility and other demographic processes. We find large educational differences across religions in India that are translating into differences in childbearing and the population growth of these groups. Increasing educational attainment is among the most important drivers of fertility differentials in the contemporary world. Therefore, depending on future education gains we can expect a different pace of fertility decline across these religious groups that will in turn affect their relative growth and age structure - and consequently influence the country's population growth, its religious composition and educational differences by religion.

\section{REFERENCES}

Abbasi-Shavazi M. J., McDonald P., Hosseini-Chavoshi M., 2009, The Fertility Transition in Iran: Revolution and Reproduction, Springer, Dordrecht.

Abou-Gamrah H., 1982, Fertility Levels and Differentials by Mother's Education in Some Countries of the ECWA Region, [in:] Determinants of Fertility in Some African and Asian Countries (p. 191-211), Research Monograph Series, vol. 10, Cairo Demographic Centre, Cairo.

Akmam W., 2002, Women's Education and Fertility Rates in Developing Countries, With Special Reference to Bangladesh, "Journal of Asian and International Bioethics", vol. 12, 138-43.

Albouy V., Lequien L., 2009, Does Compulsory Education Lower Mortality?, "Journal of Health Economics", vol. 28, no. 1, 155-68.

Bhat M., Zavier F., 2005, Role of Religion in Fertility Decline, "Economic and Political Weekly", Jan 29., 385-402. 
Bongaarts J., 2003, Completing the Fertility Transition in the Developing World: The Role of Educational Differences and Fertility Preferences, "Population Studies", vol. 57, 321-36.

Dyson T., Cassen R., Visaria L., 2005, Twenty-first century India: population, economy, human development, and the environment, "OUP Catalogue", Oxford University Press.

Fuchs R., Goujon A., 2014, Future Fertility in High Fertility Countries, [in:] Lutz W., Butz W. P., KC S. (eds.), World Population and Human Capital in the 21st Century (p. 147-225), Oxford University Press, Oxford.

Goujon A., Skirbekk V., Fliegenschnee K., Strzelecki P., 2007, New Times, Old Beliefs: Projecting the Future Size of Religions in Austria, "Vienna Yearbook of Population Research", vol. 5, 237-70.

Gulesci S., Meyersson E., 2012, 'For the Love of the Republic'Education, Religion, and Empowerment in Turkey, Working Paper available at:

http://econ.sciences-po.fr/sites/default/files/gulesci_meyersson_loverepublic.pdf .

Hackett C., Grim B., Stonawski M., Skirbekk V., Kuriakose N., Potancokova M., 2014, Methodology of the Pew Research Global Religious Landscape Study, "Yearbook of International Religious Demography", vol. 131.

Hackett C., Connor P., Stonawski M., Skirbekk V., Potancokova M., Guy A., 2015, The Future of World Religions: Population Growth Projections, 2010-2050, Pew Research Center, Washington D.C.

Heaton T. B., 2011, Does Religion Influence Fertility in Developing Countries, "Population Research and Policy Review", vol. 30, no. 3, 449-65.

Hungerman D. M., 2011, The Effect of Education on Religion: Evidence from Compulsory Schooling Laws, Working Paper no. 16973, National Bureau of Economic Research.

Jeffery R., Jeffery P., 1997, Population, Gender and Politics: Demographic Change in Rural North India, Cambridge University Press, Cambridge.

Jejeebhoy S. J., 1995, Women's Education, Autonomy, and Reproductive Behaviour: Experience from Developing Countries, Clarendon Press, Oxford.

Joseph C., 2013, Determinants of fertility differentials among the religious groups in Kerala, doctoral thesis, School of Gandhian thought and development studies, Mahatma Gandhi University, Kottayam, Kerala, http://shodhganga.inflibnet.ac.in//handle/10603/7084 .

Kaufmann E., Goujon A., Skirbekk V., 2012, The End of Secularization in Europe? A Socio-Demographic Perspective, "Sociology of Religion", vol. 73, no. 1, 69-91.

KC S., Potančoková M., Bauer R., Goujon A., Striessnig E., 2014, Data and Methods, [in:] World Population and Human Capital in the 21st Century, Lutz W., Butz W. P., Samir K. C. (eds.), World Population and Human Capital in the 21st Century (p. 147-225), Oxford University Press, Oxford.

Kravdal Ø., 2004, Child Mortality in India: The Community-Level Effect of Education, "Population Studies", vol. 58, no. 2, 177-92.

Kumar A., 2012, Religion Vis-a Vis Fertility and Family Planning Behavior in Uttar Pradesh, India, "Journal of Research in Peace Gender and Development", vol. 2, no. 1, 10-14.

Nachane D. M., 2011, India Development Report, 2011, Oxford University Press.

Norris P., Inglehart R., 2004, Sacred and Secular: Religion and Politics Worldwide, Cambridge University Press, Cambridge.

PEW, 2011, The Future of the Global Muslim Population. Projections for 2010-2030, PEW Forum on Religion and Public Life, Washington, D.C.

PEW, 2012, The Global Religious Landscape. PEW forum on religion and public life. Washington D.C. Philipov D., Rodgers A., 1981, Multistate Population Projections. IIASA, Laxenburg, Austria.

Rocca C. H., Shankar M., Sreevathsa A., Krishnan S., 2013, Acceptability and use of emergency contraception among married women in Bangalore, India, "International Journal of Gynecology \& Obstetrics", vol. 121, no. 1, 64-68.

Rogers A., 1975, Introduction to Multiregional Mathematical Demography, John Wiley \& Sons, New York.

Rogers A., 1995, Multiregional Demography: Principles, Methods and Extensions, John Wiley, Chichester. 
Ryder N. B., 1980, The Cohort Approach: Essays in the Measurement of Temporal Variations in Demographic Behavior, Ayer Publishing.

Siddiqui F., Jamal A., 2012, Fertility Differential by Education and Religion in Dhanbad District, Jharkhand (India), "The Arab World Geographer", vol. 15, no. 3, 226-42.

Skirbekk V., 2008, Fertility Trends by Social Status, "Demographic Research", vol. 18, no. 5, 145-80.

Skirbekk V., Kaufmann E., Goujon A., 2010, Secularism, Fundamentalism, or Catholicism? The Religious Composition of the United States to 2043, "Journal for the Scientific Study of Religion", vol. 49, no. 2, 293-310.

Stonawski M., Skirbekk V., Hackett C., Potancokova M., Grim B., 2014, The Size and Demographic Structure of Religions in Europe, "Yearbook of International Religious Demography", vol. 131.

Stonawski M., Skirbekk V., Kaufmann E., Goujon A., 2015, The End of Secularization through Demography? Projections of Spanish Religiosity, "Journal of Contemporary Religion", vol. 30, no. $1,1-21$.

Subramanian S.V., Nandy S., Irving M., Gordon D., Lambert H., Smith G. D., 2006, The Mortality Divide in India: The Differential Contributions of Gender, Caste, and Standard of Living Across the Life Course, "American Journal of Public Health", vol. 96, no. 5, 818-25.

Suryanarayana M., Agrawal A., Prabhu K.S., 2011, Inequality-Adjusted Human Development Index for India's States, UNDP India, New Delhi.

UN, 2013, World Population Prospects: The 2012 Revision, United Nations Population Division, New York.

University Grants Commission, 2008, Higher Education in India - Issues Related to Expansion, Inclusiveness, Quality and Finance, University Grants Commission, New Delhi.

\title{
DEMOGRAPHIC PROJECTIONS BY RELIGION AND EDUCATION IN INDIA
}

\begin{abstract}
Studying religion jointly with education allows one to produce more precise projections of the size and structure of religious communities. India's religious groups are characterized by large differences in their education and fertility levels. Among those with secondary or more education, there tends to be low variation in fertility, while for those without any education, fertility is high and varies substantially. For India, if fertility differentials were constant and there was no increase in educational enrolment, the Indian population would grow from 846 million in 2000 to more than 2.3 billion in 2050, while the Hindu population would change from $80.2 \%$ to $76.4 \%$ and the proportion of Muslims would rise from $13.4 \%$ to $19 \%$. If fertility converges and education levels increases, the population would increase to 1.7 billion by 2050 , with $78.2 \%$ Hindus and $16.5 \%$ Muslims.
\end{abstract}

Keywords: India, religion, education, multistate population projections 


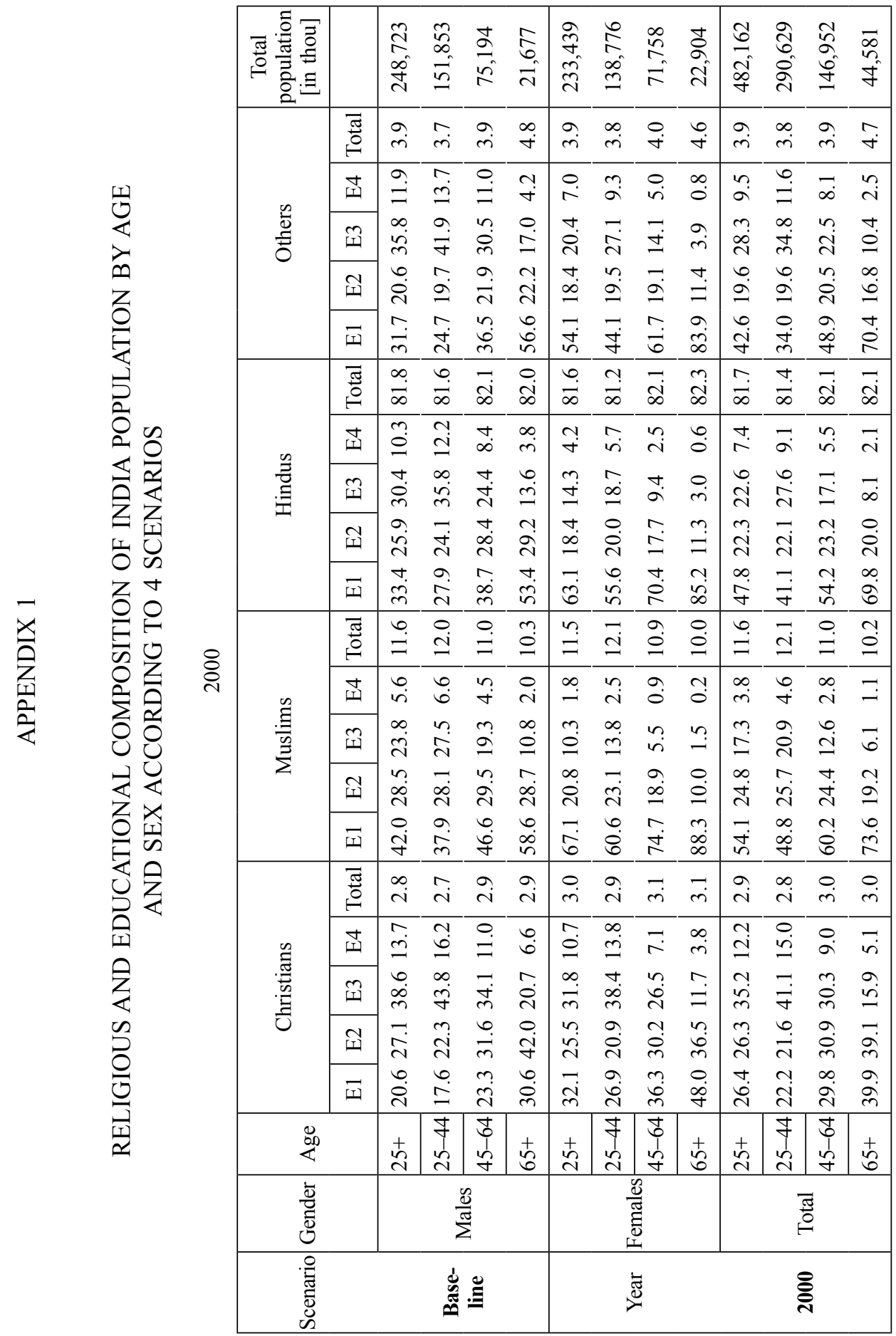




\begin{tabular}{|c|c|c|c|c|c|c|c|c|c|c|c|c|c|}
\hline \multicolumn{2}{|c|}{ 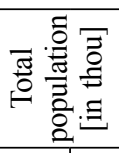 } & $\begin{array}{l}\hat{n} \\
\text { ñ } \\
\hat{n}\end{array}$ & 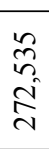 & 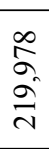 & $\begin{array}{l}\mathbb{Z} \\
\infty \\
\mathbb{D}^{+}\end{array}$ & $\begin{array}{l}\bar{\delta} \\
\infty \\
\infty \\
\infty \\
\infty\end{array}$ & $\begin{array}{l}\infty \\
\text { ñ } \\
\text { in } \\
\text { ñ. }\end{array}$ & $\begin{array}{l}\hat{n} \\
\hat{n} \\
\vec{\sim}\end{array}$ & $\begin{array}{l}\text { 尺) } \\
\text { ¿ } \\
\text { I }\end{array}$ & $\begin{array}{l}\infty \\
\stackrel{n}{+} \\
\infty \\
\vdots \\
=\end{array}$ & $\begin{array}{l}\vec{n} \\
\stackrel{n}{n} \\
n\end{array}$ & $\frac{\stackrel{0}{n}}{\frac{\vec{m}}{f}}$ & 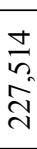 \\
\hline \multirow{5}{*}{$\begin{array}{l}\frac{n}{\Delta} \\
\frac{D}{0}\end{array}$} & 吾 & $\stackrel{\circ}{\circ}$ & $\begin{array}{l}o \\
\stackrel{i}{ }\end{array}$ & $\stackrel{\sim}{m}$ & $\begin{array}{l}0 \\
\dot{m}\end{array}$ & $\stackrel{\circ}{\circ}$ & $\begin{array}{l}o \\
\stackrel{i}{ }\end{array}$ & $\vec{m}$ & $\hat{m}$ & $\stackrel{\circ}{\circ}$ & $\begin{array}{l}o \\
\stackrel{i}{ }\end{array}$ & $\vec{m}$ & $\hat{r}$ \\
\hline & $\underset{I}{ \pm}$ & $\begin{array}{l}n \\
n \\
n\end{array}$ & $\stackrel{+}{\circ}$ & $\frac{n}{n}$ & $\begin{array}{l}0 \\
\ddot{d}\end{array}$ & $\frac{N}{n}$ & $\dot{0}$ & $\stackrel{i}{n}$ & $\stackrel{\infty}{\sim}$ & $\begin{array}{l}\stackrel{\nabla}{n} \\
\stackrel{n}{n}\end{array}$ & $\stackrel{0}{\circ}$ & $\stackrel{0}{n}$ & $\stackrel{\sim}{\tilde{v}}$ \\
\hline & ભ્વ & $\vec{\infty}$ & $\begin{array}{l}0 \\
\infty \\
\infty\end{array}$ & 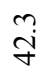 & 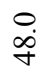 & 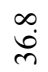 & $\stackrel{\vec{\infty}}{\sim}$ & $\begin{array}{l}\stackrel{\sim}{\sim} \\
\stackrel{f}{0}\end{array}$ & $\vec{g}$ & $\frac{\dot{m}}{m}$ & $\stackrel{\vec{\infty}}{\stackrel{\sim}{N}}$ & $\stackrel{\sim}{\mathscr{f}}$ & $\stackrel{r}{\dot{\gamma}}$ \\
\hline & న્ય & $\stackrel{0}{i n}$ & $\stackrel{\infty}{0}$ & $\stackrel{+}{\forall}$ & $\begin{array}{l}\infty \\
\dot{v}\end{array}$ & $\stackrel{?}{\forall}$ & r̦ & $\stackrel{\vec{i}}{\stackrel{d}{*}}$ & $\hat{\jmath}$ & $\stackrel{\sigma}{\underset{\sim}{*}}$ & $\tilde{0}$ & $\stackrel{\nabla}{\oplus}$ & $\stackrel{\vartheta}{\sim}$ \\
\hline & $\overline{\text { I }}$ & $\stackrel{\nabla}{\sim}$ & ก̋ & $\stackrel{\infty}{\longrightarrow}$ & $\begin{array}{l}\stackrel{0}{c} \\
\end{array}$ & $\check{r}$ & $\tilde{o}$ & $\stackrel{m}{m}$ & ָั) & $\underset{r}{i}$ & $\tilde{o}$ & $\tilde{\sim}$ & $\stackrel{\nabla}{\Delta}$ \\
\hline \multirow{5}{*}{$\begin{array}{l}\stackrel{n}{\Xi} \\
\stackrel{\Xi}{\Xi} \\
:\end{array}$} & 吾 & $\underset{\infty}{\stackrel{\infty}{\infty}}$ & $\stackrel{-}{\therefore}$ & $\begin{array}{l}\infty \\
\infty \\
\infty\end{array}$ & $\dot{\infty}$ & $\underset{\infty}{\infty}$ & $\stackrel{\circ}{\circ}$ & $\begin{array}{l}0 \\
\infty \\
\infty\end{array}$ & $\stackrel{\sim}{\infty}$ & $\underset{\infty}{\infty}$ & $\stackrel{\circ}{\stackrel{0}{*}}$ & $\underset{\infty}{\infty}$ & $\stackrel{n}{\infty}$ \\
\hline & $\underset{ \pm}{+}$ & 设 & $?$ & $\stackrel{\infty}{\dot{n}}$ & $\stackrel{+}{\stackrel{\sim}{d}}$ & $\begin{array}{l}0 \\
\text { in }\end{array}$ & $\hat{\rho}$ & نீ. & $\begin{array}{l}0 \\
\end{array}$ & $\begin{array}{l}0 \\
\hat{n}\end{array}$ & $\dddot{?}$ & $\frac{n}{n}$ & $\begin{array}{l}\infty \\
\dot{d}\end{array}$ \\
\hline & $\tilde{I}$ & ণৃ & $\begin{array}{l}0 \\
\dot{0}\end{array}$ & $\stackrel{m}{\stackrel{n}{q}}$ & $\stackrel{m}{q}$ & $\begin{array}{l}\infty \\
\dot{\sim}\end{array}$ & $\stackrel{\circ}{\infty}$ & $\stackrel{M}{\mathcal{H}}$ & $\stackrel{\vec{j}}{m}$ & $\stackrel{n}{n}$ & $\vec{\infty}$ & $\stackrel{\infty}{\dot{\square}}$ & $\stackrel{r}{\infty}$ \\
\hline & Iี & ị & $\hat{\sigma}$ & $\stackrel{g}{+}$ & $\hat{\sigma}$ & $\stackrel{\sim}{+}$ & $\widetilde{c}$ & $\stackrel{\infty}{\infty}$ & $\stackrel{+}{+}$ & $\stackrel{\sim}{\sim}$ & $n$ & $\stackrel{a}{m}$ & $\stackrel{\nabla}{\sim}$ \\
\hline & 可 & $\stackrel{\nabla}{\oplus}$ & Na & $\stackrel{\circ}{i}$ & $\begin{array}{l}0 \\
\dot{\Xi}\end{array}$ & $\hat{\infty}$ & ra & $\stackrel{m}{q}$ & $\overrightarrow{+}$ & ণֶ & ֻุ & $\vec{m}$ & $\bar{n}$ \\
\hline \multirow{6}{*}{ 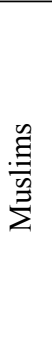 } & $\bar{\pi}$ & $\underset{\sigma}{n}$ & $\stackrel{0}{\circ}$ & $\ddot{n}$ & $\vec{\sim}$ & $\stackrel{\nabla}{0}$ & 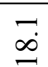 & 웅 & $\stackrel{m}{m}$ & $\underset{\sigma}{?}$ & $\vec{\infty}$ & $\ddot{g}$ & $\stackrel{\sim}{\sim}$ \\
\hline & $\underset{4}{+}$ & o & $\begin{array}{l}\dot{8} \\
\dot{8}\end{array}$ & $\begin{array}{l}0 \\
\dot{0}\end{array}$ & $\begin{array}{l}0 \\
\end{array}$ & $\dot{8}$ & $\hat{g}$ & $\begin{array}{l}\stackrel{\circ}{ } \\
\dot{f}\end{array}$ & $\stackrel{?}{=}$ & $\begin{array}{l}\vec{v} \\
\stackrel{1}{*}\end{array}$ & $\begin{array}{l}n \\
8\end{array}$ & ?ִ & $\stackrel{\sim}{ \pm}$ \\
\hline & $\widetilde{I}$ & గై & $\stackrel{m}{\circ}$ & $\stackrel{\infty}{\oplus}$ & $\stackrel{b}{=}$ & $\stackrel{0}{0}$ & $\hat{\partial}$ & ఝి & $\vec{i}$ & $\overrightarrow{0}$ & $\dddot{n}$ & 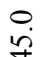 & $\stackrel{\nabla}{\circ}$ \\
\hline & $N$ & $\infty$. & 0 & 0 & 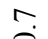 & $n$ & $m$ & $a$ & $r$ & - & 0 & $m$ & $=$ \\
\hline & & $n$ & - & 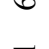 & $\stackrel{\sim}{\sim}$ & & & $m$ & $\vec{a}$ & & & & $m$ \\
\hline & $\overline{I I}$ & $\vec{\nabla}$ & ?ִ & $\vec{m}$ & $\dot{\mathrm{N}}$ & $\dot{\infty}^{\infty}$ & ?ִ & $\begin{array}{l}\infty \\
\text { in }\end{array}$ & $\stackrel{\infty}{\infty}$ & రా & ?? & $\stackrel{+}{+}$ & : \\
\hline \multirow{5}{*}{. } & స్ّ & $\stackrel{+}{i}$ & $\stackrel{m}{i}$ & $\stackrel{m}{i}$ & $\tilde{i}$ & $\stackrel{\nabla}{i}$ & $\tilde{n}$ & $\stackrel{\overbrace{}}{i}$ & $\begin{array}{l}\infty \\
i\end{array}$ & $\stackrel{\vec{i}}{\stackrel{\sim}{*}}$ & $\tilde{n}$ & $\stackrel{\tilde{N}}{\sim}$ & $\vec{i}$ \\
\hline & $\underset{I}{+}$ & $\begin{array}{l}m \\
n\end{array}$ & $\begin{array}{l}+ \\
\infty \\
\infty\end{array}$ & $\begin{array}{l}\vec{\delta} \\
\dot{\infty}\end{array}$ & ڤे & $\begin{array}{l}+ \\
\tilde{n}\end{array}$ & $\stackrel{+}{\circ}$ & $\begin{array}{l}n \\
n \\
n\end{array}$ & $\stackrel{0}{\dot{v}}$ & $\begin{array}{l}m \\
n\end{array}$ & $\hat{8}$ & $\stackrel{+}{\circ}$ & ن. \\
\hline & $\Re_{I I}$ & $\stackrel{0}{\infty}$ & $\stackrel{0}{\circ}$ & $\stackrel{\Im}{\sim}$ & $\stackrel{\Upsilon}{\alpha}$ & 9 & $\begin{array}{l}\infty \\
\infty \\
\infty\end{array}$ & 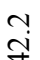 & g̊ & $\stackrel{0}{\infty}$ & $\stackrel{\sim}{2}$ & $\begin{array}{l}0 \\
\stackrel{0}{c}\end{array}$ & 9 \\
\hline & $\sim$ & 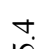 & 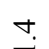 & $r$ & $\underset{\sim}{\infty}$ & 9 & $?$ & $\nabla$. & $\stackrel{\circ}{\mathrm{i}}$ & 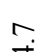 & 9 & $=$ & $\stackrel{\sim}{\sim}$ \\
\hline & $\overrightarrow{I I}$ & $m$ & $\stackrel{0}{0}$ & 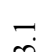 & $\stackrel{\circ}{\circ}$ & 9 & $\dot{0}$ & iे & $\vec{n}$ & $\exists$ & $n$ & 0 . & $\hat{\mathrm{j}}$ \\
\hline \multicolumn{2}{|c|}{$\underset{<}{80}$} & $\stackrel{+}{n}$ & $\begin{array}{l}\nexists \\
2\end{array}$ & 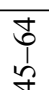 & $\frac{+}{2}$ & 古 & $\begin{array}{l}8 \\
2\end{array}$ & 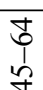 & $\frac{+}{n}$ & $\stackrel{+}{a}$ & $\begin{array}{l}\forall \\
2\end{array}$ & 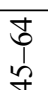 & 索 \\
\hline \multicolumn{2}{|c|}{$\begin{array}{l}\overline{\vec{d}} \\
\overline{0} \\
\overline{0}\end{array}$} & \multicolumn{4}{|c|}{$\frac{\tilde{\psi}}{\tilde{\pi}}$} & \multicolumn{4}{|c|}{$\frac{\tilde{v}}{\tilde{U}}$} & \multicolumn{4}{|c|}{ 莺 } \\
\hline \multicolumn{2}{|c|}{ 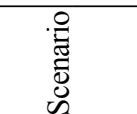 } & \multicolumn{4}{|c|}{ 至 } & \multicolumn{5}{|c|}{$\stackrel{\mathbb{J}}{\nu}$} & \multicolumn{2}{|c|}{ ஜั } & \\
\hline
\end{tabular}




\begin{tabular}{|c|c|c|c|c|c|c|c|c|c|c|c|c|c|}
\hline \multicolumn{2}{|c|}{ 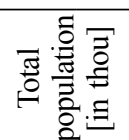 } & $\begin{array}{l}\stackrel{n}{2} \\
\hat{n} \\
\hat{n}\end{array}$ & $\begin{array}{l}\stackrel{0}{\forall} \\
\dot{v} \\
\stackrel{v}{v}\end{array}$ & $\begin{array}{l}\vec{\infty} \\
\stackrel{\alpha}{\sigma} \\
\vec{\sim}\end{array}$ & $\begin{array}{l}\mathbb{J} \\
\infty \\
\mathbb{0}\end{array}$ & 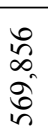 & $\begin{array}{l}\tilde{n} \\
\tilde{n} \\
\tilde{n} \\
\hat{n}\end{array}$ & $\begin{array}{l}\hat{n} \\
\tilde{n} \\
=\end{array}$ & $\begin{array}{l}\stackrel{2}{6} \\
\text { i } \\
\text { In }\end{array}$ & $\begin{array}{l}\vec{g} \\
a \\
\dot{a} \\
\vec{a}\end{array}$ & $\begin{array}{l}\hat{b} \\
\stackrel{0}{0} \\
\stackrel{+}{q}\end{array}$ & $\frac{\vec{\sigma}}{\frac{\tilde{\sigma}}{f}}$ & $\begin{array}{l}\frac{\Delta}{n} \\
\stackrel{\Delta}{\Delta}\end{array}$ \\
\hline \multirow{6}{*}{ 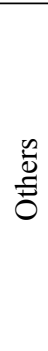 } & $\bar{\pi}$ & $\vec{m}$ & $\stackrel{\infty}{i}$ & $\stackrel{\sim}{m}$ & $\begin{array}{l}\dot{0} \\
\dot{r}\end{array}$ & $\vec{m}$ & $\stackrel{\infty}{i}$ & $\vec{m}$ & $\hat{m}$ & $\vec{m}$ & $\stackrel{\infty}{i}$ & $\vec{m}$ & $\dot{r}$ \\
\hline & $\underset{\mid}{+}$ & $n$ & $\stackrel{+}{\circ}$ & $\stackrel{n}{n}$ & $\begin{array}{l}0 \\
\ddot{n}\end{array}$ & $\stackrel{m}{\square}$ & $\grave{\rho}$ & $\stackrel{5}{n}$ & $\stackrel{\infty}{\sim}$ & $\stackrel{\nabla}{i}$ & $\stackrel{0}{\circ}$ & $\stackrel{0}{\overrightarrow{0}}$ & $\tilde{\vartheta}$ \\
\hline & $\widetilde{I}$ & $\vec{\infty}$ & $\underset{\infty}{0}$ & $\stackrel{m}{i}$ & $\underset{\infty}{\circ}$ & $\underset{0}{\infty}$ & $\ddot{\infty}$ & $\begin{array}{l}0 \\
i\end{array}$ & $\overrightarrow{0}$ & $\underset{r}{\stackrel{r}{r}}$ & $\vec{\infty}$ & $\tilde{n}$ & $\dot{m}$ \\
\hline & $N$ & 0 . & $\infty$. & $\nabla$ & $\infty$. & 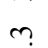 & ก! & $\nabla$ & & 0 & $n$ & $\nabla$ & $?$ \\
\hline & 工I & $n$ & 0 & $\dot{\nabla}$ & $\underline{n}$ & $\dot{\nabla}$ & 0 & i & $\simeq$ & $\dot{\forall}$ & 0 & $\dot{m}$ & \\
\hline & 피 & $\stackrel{\nabla}{\dot{r}}$ & $\stackrel{N}{0}$ & $\stackrel{\infty}{-}$ & $\begin{array}{l}\text { o. } \\
\stackrel{\sim}{c}\end{array}$ & $\stackrel{r}{r}$ & กั & $\ddot{n}$ & ָै & $\begin{array}{l}0 \\
\dot{n}\end{array}$ & $\stackrel{\sim}{0}$ & $\tilde{n}$ & $\stackrel{\nabla}{\stackrel{\Delta}{2}}$ \\
\hline \multirow{6}{*}{$\stackrel{\tilde{z}}{\tilde{\Xi}}$} & त्ञ & $\vec{\infty}$ & $\stackrel{尺}{尺}$ & $\stackrel{a}{\infty}$ & $\ddot{0}$ & $\begin{array}{l}0 \\
\infty \\
\infty\end{array}$ & $\stackrel{\Re}{尺}$ & $\underset{\infty}{\infty}$ & $\stackrel{\sim}{\stackrel{\infty}{\infty}}$ & $\begin{array}{l}0 \\
\infty \\
\infty\end{array}$ & $\stackrel{i}{i}$ & $\begin{array}{l}\infty \\
\infty \\
\infty\end{array}$ & $\stackrel{n}{\infty}$ \\
\hline & $\underset{ \pm}{+}$ & $\begin{array}{l}\infty \\
+ \\
+\end{array}$ & $\stackrel{n}{9}$ & $\stackrel{\infty}{-}$ & $\begin{array}{l}\stackrel{+}{+} \\
\stackrel{2}{*}\end{array}$ & $\stackrel{0}{1}$ & $\hat{\rho}$ & $\begin{array}{l}0 \\
0\end{array}$ & $\stackrel{0}{\circ}$ & N̦ & $\dddot{?}$ & 굼 & $\stackrel{\infty}{\circ}$ \\
\hline & $m$ & m? & 0 & ? & $m$ & 0 & $\partial$ & $?$ & 9 & $r$ & $r$ & $\infty$ & $r$ \\
\hline & 工工 & m & $\stackrel{\infty}{N}$ & $\vec{\gamma}$ & 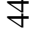 & $m$ & $\stackrel{\infty}{\sim}$ & $\stackrel{F}{f}$ & $\stackrel{m}{m}$ & $m$ & $\stackrel{\infty}{\sim}$ & $\vec{\gamma}$ & $\underset{n}{\infty}$ \\
\hline & 工્ & 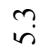 & $\ddot{0}$ & $\stackrel{g}{\dot{\gamma}}$ & $\ddot{\sigma}$ & $\stackrel{?}{\forall}$ & $\stackrel{1}{0}$ & $\stackrel{\infty}{\sim}$ & $\stackrel{\nabla}{ \pm}$ & $\stackrel{\infty}{\stackrel{\infty}{\forall}}$ & $\stackrel{0}{0}$ & ले & $\stackrel{\nabla}{\sim}$ \\
\hline & 可 & $\ddot{n}$ & r̦ & $\stackrel{\circ}{i}$ & $\begin{array}{l}\bullet \\
\dot{J}\end{array}$ & à & r̦ & $\dddot{r}$ & 方 & ?ु? & $\stackrel{N}{0}$ & $\vec{m}$ & $\vec{a}$ \\
\hline \multirow{6}{*}{$\frac{\mathscr{\Xi}}{\underbrace{\mathscr{\Xi}}}$} & $\bar{\pi}$ & $\begin{array}{l}\infty \\
i\end{array}$ & 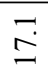 & $\begin{array}{l}0 \\
\ddot{n}\end{array}$ & $\vec{g}$ & â & $\stackrel{1}{I}$ & O & $\stackrel{m}{m}$ & $\begin{array}{l}\infty \\
\end{array}$ & $\stackrel{r}{I}$ & $\begin{array}{l}\infty \\
\stackrel{n}{n}\end{array}$ & $\ddot{\sim}$ \\
\hline & $\underset{I}{+}$ & $\underset{\sim}{\stackrel{0}{.}}$ & $\stackrel{m}{a}$ & $\tilde{0}$ & $\underset{\sim}{\circ}$ & $\begin{array}{l}0 \\
9\end{array}$ & $\begin{array}{l}0 \\
\stackrel{0}{0}\end{array}$ & $\stackrel{\circ}{\dot{I}}$ & $\stackrel{?}{=}$ & $?$ & $\tilde{a}$ & $\stackrel{m}{n}$ & $\stackrel{\sim}{+}$ \\
\hline & 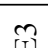 & $\ddot{0}$ & $\stackrel{\nabla}{\sigma}$ & $\infty$ & بـ & ț. & $\infty$ & ņ & $\vec{i}$ & 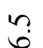 & $\ddot{g}$ & 0 & ț. \\
\hline & 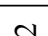 & - & - & 6 & $r$ & $\infty$ & $m$ & $a$ & $r$ & $\forall$ & 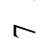 & $m$ & - \\
\hline & I & $0^{\circ}$ & - & $\ddot{0}$ & ¿ & $\dot{\nabla}$ & $\stackrel{0}{0}$ & $\dot{r}$ & $I$ & $\ddot{n}$ & $0^{\circ}$ & in & 2 \\
\hline & 피 & $\stackrel{m}{\forall}$ & ?? & $\vec{m}$ & $\vec{d}$ & $\tilde{a}$ & $\stackrel{n}{0}$ & $\stackrel{\infty}{\dot{n}}$ & $\begin{array}{l}a \\
\infty\end{array}$ & $\underset{0}{\infty}$ & $\stackrel{n}{0}$ & $\stackrel{ナ}{+}$ & $\stackrel{?}{\rho}$ \\
\hline \multirow{6}{*}{ 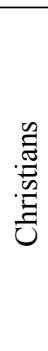 } & $\bar{\pi}$ & $\stackrel{+}{i}$ & $\stackrel{+}{i}$ & $\stackrel{m}{c}$ & $\stackrel{n}{\sim}$ & $\stackrel{\vec{v}}{\mathrm{v}}$ & $\stackrel{n}{d}$ & $\tilde{n}$ & $\stackrel{\infty}{\sim}$ & $\stackrel{\sim}{\sim}$ & $\stackrel{+}{i}$ & $\stackrel{n}{\sim}$ & $\hat{\sim}$ \\
\hline & $\underset{ \pm}{+}$ & $\widehat{a}$ & $\begin{array}{l}n \\
\infty\end{array}$ & $\begin{array}{l}n \\
\infty\end{array}$ & $\ddot{a}$ & $\stackrel{0}{\circ}$ & $\stackrel{+}{\circ}$ & $\begin{array}{l}0 \\
i \\
i\end{array}$ & Oे & $\stackrel{0}{\circ}$ & $\hat{g}$ & ?? & $\stackrel{0}{\circ}$ \\
\hline & II & $\underset{\infty}{\infty}$ & $\stackrel{\circ}{\circ}$ & $\stackrel{\infty}{i}$ & 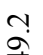 & $\underset{\infty}{\infty}$ & $\begin{array}{l}\infty \\
\infty \\
\infty\end{array}$ & $\tilde{N}$ & જે & $\vec{\infty}$ & ָุ' & $\tilde{n}$ & $\stackrel{9}{2}$ \\
\hline & $\sim$ & $n$ & $\nabla$ & 0 & $\infty$ & 0 & $\nabla$ & $\nabla$ & 0 & $\infty$. & $a$ & - & บ \\
\hline & & & - & & $\simeq$ & & & & & & & & \\
\hline & $\overline{\text { I }}$ & $\ddot{m}$ & $\ddot{0}$ & $\stackrel{0}{\dot{m}}$ & $\dot{0}$ & ị. & $\tilde{o}$ & $\stackrel{\infty}{\sim}$ & $\ddot{n}$ & $\exists$ & $\stackrel{b}{0}$ & $\hat{i}$ & $\stackrel{\mathcal{I}}{\simeq}$ \\
\hline \multicolumn{2}{|c|}{$\underset{\&}{\infty}$} & 点 & $\begin{array}{l}\text { \& } \\
2 \\
\end{array}$ & 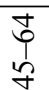 & $\sqrt{6}$ & 点 & $\begin{array}{l}\forall \\
\stackrel{2}{2}\end{array}$ & $\begin{array}{l}\mathbb{J} \\
1 \\
\vdots \\
f\end{array}$ & $\frac{+}{6}$ & 点 & 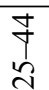 & $\begin{array}{l}\text { J } \\
1 \\
\vdots \\
y\end{array}$ & $\stackrel{+}{6}$ \\
\hline \multicolumn{2}{|c|}{$\begin{array}{l}\dot{\bar{\theta}} \\
\overrightarrow{0} \\
\overrightarrow{0}\end{array}$} & \multicolumn{4}{|c|}{$\frac{\infty}{\sum^{\pi}}$} & \multicolumn{4}{|c|}{ 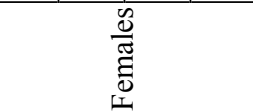 } & \multicolumn{4}{|c|}{ 吾 } \\
\hline \multicolumn{2}{|c|}{ 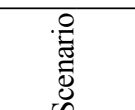 } & \multicolumn{4}{|c|}{ 占地 } & \multicolumn{5}{|c|}{$\stackrel{\Xi}{\circlearrowright}$} & \multicolumn{2}{|c|}{ ஜั } & \\
\hline
\end{tabular}




\begin{tabular}{|c|c|c|c|c|c|c|c|c|c|c|c|c|c|}
\hline \multicolumn{2}{|c|}{ 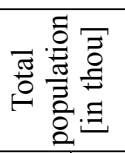 } & 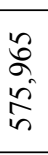 & 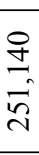 & 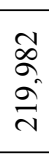 & $\begin{array}{l}\mathbb{J} \\
\infty \\
+0 \\
\dot{0}\end{array}$ & $\begin{array}{l}\nabla \\
\infty \\
0 \\
\mathbb{\delta}^{\circ} \\
i n\end{array}$ & $\begin{array}{l}\bar{\sigma} \\
\tilde{d} \\
\tilde{d}\end{array}$ & $\begin{array}{l}\tilde{n} \\
\hat{n} \\
\equiv \\
\bar{\sim}\end{array}$ & $\begin{array}{l}\stackrel{2}{6} \\
\text { I } \\
\text { I }\end{array}$ & 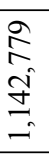 & $\begin{array}{l}\vec{n} \\
\text { ma } \\
\infty \\
\infty\end{array}$ & $\frac{n}{n}$ & 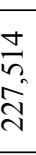 \\
\hline \multirow{5}{*}{$\frac{\mathscr{\omega}}{\overrightarrow{0}}$} & స్ㅠㅇ & $\vec{m}$ & $\vec{i}$ & $\stackrel{\sim}{m}$ & $\stackrel{b}{\dot{r}}$ & $\vec{m}$ & $\hat{\mathrm{i}}$ & $\vec{m}$ & $\vec{r}$ & $\vec{m}$ & $\hat{i}$ & $\vec{m}$ & $\vec{m}$ \\
\hline & 吉 & $\stackrel{\vartheta}{\ddot{\nu}}$ & $\begin{array}{l}\stackrel{\circ}{ \pm} \\
\end{array}$ & $\dot{\tilde{g}}$ & $\begin{array}{l}\infty \\
\dot{\sim}\end{array}$ & $\stackrel{\nabla}{\sigma}$ & $\stackrel{\infty}{a}$ & aे & $\vec{a}$ & 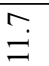 & 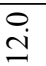 & $\stackrel{0}{=}$ & 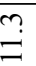 \\
\hline & ભิ & $\begin{array}{l}\underset{\sim}{c} \\
\text { in }\end{array}$ & $\stackrel{\nabla}{\oplus}$ & $\stackrel{\sim}{ָ}$ & $\stackrel{9}{=}$ & $\underset{\infty}{\infty}$ & $\stackrel{\text { กุ }}{\circ}$ & $\frac{9}{2}$ & $\underset{\sim}{\stackrel{\Delta}{*}}$ & $\ddot{n}$ & $\begin{array}{l}0 \\
\dot{0}\end{array}$ & n? & $\underset{\dot{J}}{\stackrel{0}{0}}$ \\
\hline & న్ & $\ddot{a}$ & $\stackrel{\nabla}{\sigma}$ & $\stackrel{\infty}{\stackrel{\infty}{\rho}}$ & $\ddot{a}$ & $\ddot{\sigma}$ & $\ddot{a}$ & & $\stackrel{a}{\partial}$ & $\ddot{\sigma}$ & $\dddot{a}$ & $\stackrel{\infty}{\stackrel{a}{a}}$ & $\stackrel{\partial}{a}$ \\
\hline & 포 & $\begin{array}{l}\infty \\
\stackrel{\sim}{~}\end{array}$ & $\overrightarrow{\ddot{v}}$ & $\underset{d}{\stackrel{d}{~}}$ & $\underset{⿱}{\stackrel{+}{\sim}}$ & $\begin{array}{l}\stackrel{0}{\sim} \\
\stackrel{\sim}{f}\end{array}$ & $\frac{⿱ 亠 䒑}{\nabla}$ & 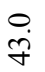 & $\begin{array}{l}\stackrel{0}{\sim} \\
\stackrel{\sim}{+}\end{array}$ & $\vec{m}$ & $\frac{\sigma}{m}$ & $\stackrel{\sim}{m}$ & $\begin{array}{l}\infty \\
\stackrel{+}{\oplus}\end{array}$ \\
\hline \multirow{5}{*}{$\stackrel{n}{\Xi}$} & 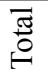 & $\underset{\infty}{\stackrel{0}{*}}$ & $\stackrel{\circ}{\stackrel{\circ}{1}}$ & 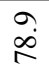 & $\ddot{\infty}$ & $\stackrel{\infty}{\infty}$ & $\stackrel{\circ}{\stackrel{0}{1}}$ & $\begin{array}{l}0 \\
\infty \\
\infty\end{array}$ & 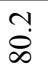 & $\underset{\infty}{\stackrel{\nabla}{\phi}}$ & $\begin{array}{l}\stackrel{\circ}{R} \\
\stackrel{1}{1}\end{array}$ & $\begin{array}{l}\infty \\
\infty \\
\infty\end{array}$ & $\stackrel{n}{\infty}$ \\
\hline & $\underset{ \pm}{ \pm}$ & $\begin{array}{l}\mathbf{0} \\
\stackrel{\sim}{c}\end{array}$ & $\overline{\grave{d}}$ & $\stackrel{+}{\stackrel{J}{c}}$ & $\stackrel{\stackrel{\sim}{\sim}}{\sim}$ & $\stackrel{0}{0}$ & ণู & $\begin{array}{l}\infty \\
\dot{n}\end{array}$ & $\overrightarrow{i n}$ & $\tilde{a}$ & $\stackrel{0}{\circ}$ & مै & $\begin{array}{l}\infty \\
\infty \\
\infty\end{array}$ \\
\hline & ભ & $\stackrel{\infty}{0}$ & $\stackrel{n}{n}$ & $\ddot{0}$ & $\overrightarrow{0}$ & $\stackrel{ナ}{\circ}$ & $\overrightarrow{0}$ & $\stackrel{\circ}{9}$ & $\stackrel{\sim}{\infty}$ & $\stackrel{\sim}{\infty}$ & $\vec{a}$ & $\stackrel{\leftrightarrow}{\vec{\sigma}}$ & $\begin{array}{l}\infty \\
0 \\
0\end{array}$ \\
\hline & Iิ & $\ddot{\sim}$ & $\stackrel{m}{\tilde{c}}$ & $\ddot{n}$ & $\vec{\partial}$ & ָे & 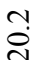 & $\vec{\circ}$ & $\overrightarrow{8}$ & $\stackrel{\infty}{\vec{\nabla}}$ & $\stackrel{\infty}{\vec{\lambda}}$ & $\stackrel{\Xi}{\vec{\lambda}}$ & $\overline{\vec{a}}$ \\
\hline & 可 & $\vec{\Delta}$ & "n & $\stackrel{n}{\sim}$ & $\stackrel{\infty}{\stackrel{\infty}{\sim}}$ & $\begin{array}{l}n \\
\stackrel{n}{n}\end{array}$ & $\begin{array}{l}\stackrel{\nabla}{n} \\
\stackrel{n}{n}\end{array}$ & $\begin{array}{l}0 \\
\ddot{n}\end{array}$ & $\begin{array}{l}n \\
n \\
n\end{array}$ & $\hat{\dot{q}}$ & $\stackrel{\nabla}{\stackrel{\nabla}{\circ}}$ & $\stackrel{0}{\stackrel{\dot{\nabla}}{ }}$ & 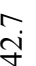 \\
\hline \multirow{5}{*}{ 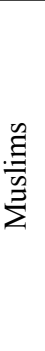 } & $\bar{\pi}$ & $\underset{\sigma}{ }$ & $\ddot{\infty}$ & $\begin{array}{l}0 \\
\ddot{n}\end{array}$ & $\vec{\sim}$ & $\stackrel{?}{6}$ & $\underset{\infty}{\tilde{\infty}}$ & $\underset{0}{0}$ & $\stackrel{m}{n}$ & $\stackrel{?}{6}$ & $\underset{\infty}{\infty}$ & $\begin{array}{l}\infty \\
\ddot{n}\end{array}$ & $\stackrel{\sim}{\dddot{m}}$ \\
\hline & $\stackrel{+}{ \pm}$ & $\hat{b}$ & $\hat{\sigma}$ & $\tilde{\sigma}$ & $\ddot{0}$ & $\begin{array}{l}0 \\
i\end{array}$ & $\begin{array}{l}\infty \\
i \\
i\end{array}$ & $\stackrel{n}{\sim}$ & $\stackrel{n}{\sim}$ & $\stackrel{r}{r}$ & $\stackrel{\vartheta}{\dot{f}}$ & $\stackrel{0}{+}$ & $\stackrel{+}{+}$ \\
\hline & ભ & $\vec{\infty}$ & $\stackrel{a}{\infty}$ & $\begin{array}{l}n \\
\infty \\
\infty\end{array}$ & $\begin{array}{c}n \\
\infty \\
\sim\end{array}$ & $\stackrel{Ð}{ \pm}$ & $\stackrel{m}{n}$ & $\stackrel{?}{ \pm}$ & $\begin{array}{l}\stackrel{ }{ \pm} \\
\end{array}$ & i & $\stackrel{\overbrace{}}{\approx}$ & $\stackrel{+}{\sim}$ & 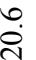 \\
\hline & I & $\begin{array}{l}\stackrel{0}{\sim} \\
\text { 作 }\end{array}$ & $\stackrel{i}{\sim}$ & $\underset{\sim}{\Delta}$ & $\frac{n}{\sim}$ & $\begin{array}{l}\dot{\sim} \\
\ddot{\sim}\end{array}$ & $\begin{array}{l}\ddot{0} \\
\dot{\sim}\end{array}$ & $\stackrel{m}{\sim}$ & $\underset{\sim}{\sim}$ & $\begin{array}{l}n \\
\sim \\
\sim\end{array}$ & in & $\begin{array}{l}+ \\
\stackrel{a}{\sim}\end{array}$ & $\begin{array}{l}\text { Nָ } \\
\end{array}$ \\
\hline & 피 & $\vec{m}$ & $\begin{array}{l}0 \\
\dot{0}\end{array}$ & $\underset{m}{\stackrel{+}{m}}$ & $\underset{m}{\stackrel{0}{m}}$ & n̊? & $\begin{array}{c}m \\
\infty \\
i n\end{array}$ & ळे & ?ִ & $\vec{\infty}$ & $\underset{\frac{\pi}{\sigma}}{ }$ & $\begin{array}{l}0 \\
\infty \\
\stackrel{+}{+}\end{array}$ & aे \\
\hline \multirow{6}{*}{ 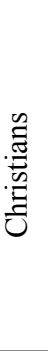 } & 胥 & $\stackrel{n}{\sim}$ & ָָ & $\tilde{n}$ & $\stackrel{n}{\sim}$ & $\stackrel{n}{\sim}$ & $\vec{i}$ & $\stackrel{n}{\sim}$ & $\stackrel{\infty}{\sim}$ & $\stackrel{n}{\sim}$ & ָָ & $\stackrel{n}{\sim}$ & $\vec{i}$ \\
\hline & 吉 & $\overrightarrow{0}$ & $\tilde{\sigma}$ & $\ddot{n}$ & $\stackrel{\sim}{\sim}$ & $\stackrel{+}{\beth}$ & $\begin{array}{l}0 \\
\text { ㅁ․ }\end{array}$ & $\stackrel{?}{ \pm}$ & 主 & $\stackrel{m}{n}$ & iे & $\begin{array}{l}\circ \\
\ddot{n}\end{array}$ & $\begin{array}{l}\infty \\
\dot{\Xi}\end{array}$ \\
\hline & ભ & ִָ & $\stackrel{a}{\square}$ & $\begin{array}{l}0 \\
\dot{0}\end{array}$ & $\ddot{g}$ & $\ddot{q}$ & $\stackrel{+}{\dot{\theta}}$ & $\vec{g}$ & $\stackrel{0}{0}$ & $\vec{\vartheta}$ & $\stackrel{m}{\vartheta}$ & $\begin{array}{l}\dot{\ominus} \\
\dot{\theta}\end{array}$ & $\stackrel{m}{\sim}$ \\
\hline & N & $\stackrel{\infty}{0}$ & $\tilde{0}$ & $\hat{0}$ & $\exists$ & $\stackrel{0}{0}$ & $\tilde{a}$ & $\stackrel{0}{0}$ & 9 à & ִָ & $\stackrel{0}{0}$ & ִָ & t. \\
\hline & [디 & ते & तิ & సิ & $\bar{\sim}$ & $\stackrel{2}{ }$ & $\stackrel{2}{ }$ & $\stackrel{2}{ }$ & $\stackrel{2}{ }$ & ते & તે & ิ & సิ \\
\hline & $\overrightarrow{\text { 도 }}$ & $\stackrel{\vartheta}{0}$ & $\hat{\sigma}$ & $\stackrel{0}{I}$ & $\stackrel{?}{\stackrel{n}{I}}$ & $\begin{array}{l}\infty \\
\ddot{\imath}\end{array}$ & $\begin{array}{l}n \\
\sim\end{array}$ & $\stackrel{0}{0}$ & $\underset{\sim}{\stackrel{\nabla}{\sim}}$ & $\stackrel{\stackrel{\nabla}{\sim}}{\stackrel{\sim}{*}}$ & $\begin{array}{l}\infty \\
\stackrel{\sim}{\sim}\end{array}$ & $\stackrel{+}{\dot{\sim}}$ & ন্ন \\
\hline \multicolumn{2}{|c|}{$\stackrel{8}{<}$} & 点 & \begin{tabular}{l}
$\nexists$ \\
\multirow{2}{*}{} \\
$\sim$
\end{tabular} & $\begin{array}{l}\forall \\
0 \\
1 \\
\ddots\end{array}$ & $\frac{+}{6}$ & 点 & $\begin{array}{l}\nexists \\
⿱ ⺌ \\
\sim\end{array}$ & 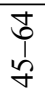 & $\frac{+}{6}$ & 点 & 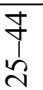 & 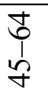 & 6 \\
\hline \multicolumn{2}{|c|}{ 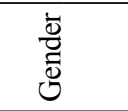 } & \multicolumn{4}{|c|}{ 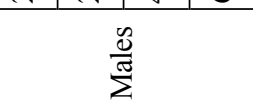 } & \multicolumn{4}{|c|}{$\frac{\dot{v}}{\tilde{J}}$} & \multicolumn{4}{|c|}{ 氶 } \\
\hline \multicolumn{2}{|c|}{ 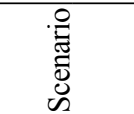 } & \multicolumn{4}{|c|}{ 窇 } & \multicolumn{5}{|c|}{ 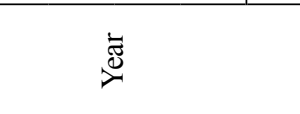 } & \multicolumn{2}{|c|}{ ஜֶ. } & \\
\hline
\end{tabular}




\begin{tabular}{|c|c|c|c|c|c|c|c|c|c|c|c|c|c|}
\hline \multicolumn{2}{|c|}{ 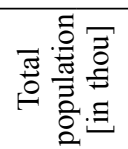 } & $\begin{array}{l}\mathbb{Z} \\
0 \\
\infty \\
0 \\
0\end{array}$ & $\frac{q}{\stackrel{2}{r}}$ & 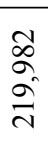 & 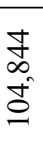 & $\begin{array}{l}a \\
\text { ปิ } \\
\text { ลู }\end{array}$ & $\frac{0}{a}$ & 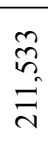 & $\begin{array}{l}\text { Ð } \\
\text { i } \\
\text { I }\end{array}$ & $\begin{array}{l}\tilde{2} \\
\infty \\
\tilde{b} \\
\stackrel{-}{=}\end{array}$ & \begin{tabular}{l}
$\Re$ \\
2 \\
\multirow{8}{0}{}
\end{tabular} & $\frac{n}{n}$ & 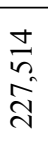 \\
\hline \multirow{5}{*}{$\begin{array}{l}\text { D. } \\
\frac{ \pm}{0} \\
\end{array}$} & 元 & $\stackrel{0}{\dot{m}}$ & $\bar{i}$ & $\stackrel{\sim}{m}$ & $\begin{array}{l}\sigma \\
\ddot{r}\end{array}$ & $\stackrel{\circ}{\oplus}$ & $\bar{\sim}$ & $\vec{m}$ & $\hat{m}$ & $\stackrel{\circ}{\dot{r}}$ & $\hat{i}$ & $\vec{m}$ & $\hat{r}$ \\
\hline & $\stackrel{+}{ \pm}$ & $\stackrel{a}{\ddot{n}}$ & $\overrightarrow{ \pm}$ & $\stackrel{\vartheta}{\partial}$ & $\begin{array}{l}\infty \\
\ddot{\nu}\end{array}$ & $\tilde{a}$ & aे & $\tilde{a}$ & $\vec{a}$ & $\exists$ & $\overrightarrow{\check{C}}$ & $\begin{array}{l}0 \\
\Xi\end{array}$ & $\stackrel{?}{=}$ \\
\hline & $\widehat{I I}$ & $\begin{array}{l}\stackrel{\infty}{\text { I }} \\
\underset{f}{2}\end{array}$ & $\begin{array}{l}\dot{\sigma} \\
\dot{\gamma}\end{array}$ & $\stackrel{\sim}{\underset{f}{*}}$ & $\frac{\Im}{\ni}$ & $\underset{\sim}{\stackrel{\dot{\infty}}{\sim}}$ & $\stackrel{\nabla}{\stackrel{\sim}{~}}$ & $\frac{a}{N}$ & $\stackrel{\nabla}{\stackrel{\Delta}{N}}$ & $\begin{array}{l}o \\
\ddot{n} \\
\ddot{m}\end{array}$ & în & $\stackrel{m}{n}$ & $\begin{array}{l}\text { ํ. } \\
\text { m }\end{array}$ \\
\hline & I & $\begin{array}{l}0 \\
\stackrel{0}{0}\end{array}$ & $\stackrel{\nabla}{\Delta}$ & $\stackrel{\infty}{\stackrel{\infty}{a}}$ & $\stackrel{a}{\partial}$ & $\stackrel{\circ}{a}$ & $\tilde{a}$ & 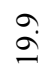 & $\stackrel{a}{\partial}$ & $\ddot{\varrho}$ & $\stackrel{+}{\circ}$ & $\begin{array}{l}\infty \\
\stackrel{\infty}{二}\end{array}$ & $\stackrel{a}{\partial}$ \\
\hline & $\overrightarrow{\text { 디 }}$ & $\hat{\vec{v}}$ & $\stackrel{0}{\stackrel{d}{d}}$ & $\underset{d}{\stackrel{D}{~}}$ & $\underset{\sim}{\stackrel{\sim}{\sim}}$ & $\stackrel{+}{\stackrel{f}{f}}$ & $\stackrel{\sim}{\forall}$ & $\stackrel{\circ}{\ddot{\gamma}}$ & $\begin{array}{l}\dot{0} \\
\dot{y}\end{array}$ & 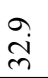 & $\stackrel{\infty}{-}$ & $\stackrel{\sim}{m}$ & $\begin{array}{l}\infty \\
\dot{m}\end{array}$ \\
\hline \multirow{5}{*}{ 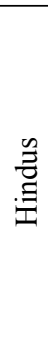 } & 曹 & $\stackrel{m}{\infty}$ & $\vec{R}$ & 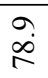 & $\ddot{\infty}$ & $\underset{\infty}{\infty}$ & $\underset{1}{\stackrel{0}{2}}$ & $\begin{array}{l}0 \\
\infty \\
\infty\end{array}$ & $\stackrel{\infty}{\infty}$ & $\stackrel{m}{\infty}$ & $\stackrel{7}{R}$ & $\begin{array}{l}\infty \\
\infty \\
\infty\end{array}$ & $\stackrel{\infty}{\infty}$ \\
\hline & 吉 & $\begin{array}{l}\underset{0}{0} \\
\stackrel{d}{ }\end{array}$ & $\begin{array}{l}\infty \\
\stackrel{1}{~}\end{array}$ & $\stackrel{ \pm}{\stackrel{ \pm}{J}}$ & $\stackrel{ナ}{\stackrel{\sim}{\beth}}$ & $\stackrel{0}{0}$ & ?ֶ. & $\begin{array}{l}\infty \\
\dot{n}\end{array}$ & $\vec{n}$ & $\ddot{a}$ & $\hat{a}$ & $\stackrel{\sim}{a}$ & $\begin{array}{l}\infty \\
\infty\end{array}$ \\
\hline & $\tilde{I}$ & @ి & $\frac{0}{n}$ & 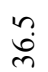 & $\overrightarrow{0}$ & $\dddot{a}$ & $\stackrel{\text { }}{\stackrel{N}{ }}$ & $\stackrel{0}{\stackrel{9}{2}}$ & $\ddot{\infty}$ & $\begin{array}{l}m \\
\infty \\
\sim\end{array}$ & ஷे & $\frac{a}{\Delta}$ & $\begin{array}{l}\infty \\
\stackrel{\sim}{\sim} \\
\text {. }\end{array}$ \\
\hline & I & $\underset{\sim}{\ddot{d}}$ & $\stackrel{m}{2}$ & $\stackrel{n}{2}$ & $\vec{\jmath}$ & 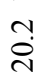 & $\stackrel{m}{?}$ & $\overrightarrow{0}$ & $\overrightarrow{0}$ & $\stackrel{\infty}{\sim}$ & $\frac{\infty}{\Delta}$ & $\stackrel{a}{\sim}$ & i. \\
\hline & $\overline{\text { 피 }}$ & $\underset{\sim}{\stackrel{0}{N}}$ & $\underset{\sim}{\stackrel{\leftrightarrow}{~}}$ & $\frac{n}{N}$ & $\stackrel{\infty}{\stackrel{N}{N}}$ & m & ஸे & $\begin{array}{l}0 \\
\text { in }\end{array}$ & $\begin{array}{l}n \\
n \\
n\end{array}$ & $\stackrel{n}{q}$ & $\stackrel{m}{m}$ & $\stackrel{0}{\dot{g}}$ & $\stackrel{\sim}{\stackrel{\sim}{f}}$ \\
\hline \multirow{5}{*}{$\frac{\mathscr{\Xi}}{: \Xi}$} & 曹 & $\stackrel{\nabla}{\sigma}$ & $\stackrel{\circ}{\infty}$ & $\begin{array}{l}0 \\
n \\
n\end{array}$ & $\vec{n}$ & $\ddot{n}$ & $\stackrel{\sim}{\infty}$ & $\stackrel{\circ}{6}$ & $\stackrel{m}{m}$ & $\stackrel{\forall}{\bullet}$ & $\vec{\infty}$ & $\begin{array}{l}\infty \\
\stackrel{\sim}{\simeq}\end{array}$ & $\stackrel{\sim}{n}$ \\
\hline & 吉 & $\stackrel{\infty}{0}$ & $\hat{\sigma}$ & $\hat{\sigma}$ & $\begin{array}{l}0 \\
0\end{array}$ & $\begin{array}{l}0 \\
\stackrel{\sim}{N}\end{array}$ & $\begin{array}{l}\infty \\
i\end{array}$ & $\tilde{n}$ & $\tilde{n}$ & $\ddot{\gamma}$ & $\dot{\gamma}$ & $\stackrel{\odot}{+}$ & $\stackrel{+}{\forall}$ \\
\hline & $\tilde{I}$ & $\vec{i}$ & $\begin{array}{l}\text { aे } \\
\dot{N}\end{array}$ & $\begin{array}{l}n \\
\infty \\
\sim\end{array}$ & $\begin{array}{l}m \\
\infty \\
\sim\end{array}$ & $\begin{array}{l}\infty \\
\dot{\Xi}\end{array}$ & $\begin{array}{l}\forall \\
\stackrel{\nabla}{n}\end{array}$ & $\stackrel{n}{ \pm}$ & $\stackrel{\circ}{\stackrel{+}{ \pm}}$ & $\stackrel{\infty}{\stackrel{\sim}{\sim}}$ & 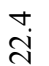 & $\stackrel{+}{\dot{\sim}}$ & $\begin{array}{l}0 \\
\stackrel{\sim}{8}\end{array}$ \\
\hline & I & $\begin{array}{l}0 \\
\stackrel{\sim}{\sim}\end{array}$ & 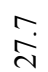 & $\underset{⿱ 亠}{\Delta}$ & $\frac{n}{\sim}$ & $\ddot{\sim}$ & $\begin{array}{l}\stackrel{0}{d} \\
\stackrel{\sim}{0}\end{array}$ & $\ddot{n}$ & ָे & $\begin{array}{l}n \\
n\end{array}$ & $\ddot{n}$ & $\begin{array}{l}\ddot{\imath} \\
\ddot{d}\end{array}$ & iֶ \\
\hline & 피 & $\underset{m}{\stackrel{0}{m}}$ & $\ddot{n}$ & $\frac{⿱ 亠}{m}$ & $\underset{m}{m}$ & $\vec{i}$ & in & à & n̊ & $\frac{9}{\dot{\gamma}}$ & $\stackrel{\circ}{\stackrel{一}{f}}$ & $\begin{array}{l}0 \\
\infty \\
+\end{array}$ & $\stackrel{g}{g}$ \\
\hline \multirow{5}{*}{ 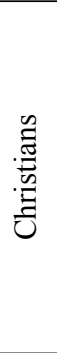 } & 要 & $\stackrel{\overbrace{}}{n}$ & $\vec{i}$ & $\stackrel{m}{\sim}$ & $\stackrel{n}{\sim}$ & $\stackrel{n}{\sim}$ & $\vec{i}$ & $\tilde{n}$ & $\stackrel{\infty}{\sim}$ & $\stackrel{m}{\sim}$ & $\overrightarrow{\mathrm{i}}$ & $\stackrel{n}{i}$ & $\bar{i}$ \\
\hline & 吉 & గֶ. & $\stackrel{\infty}{0}$ & $\stackrel{i}{n}$ & $\stackrel{n}{n}$ & $\begin{array}{l}\stackrel{0}{ } \\
\dot{I}\end{array}$ & $\vec{n}$ & $\stackrel{?}{ \pm}$ & 寻 & 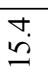 & $\stackrel{0}{0}$ & $\begin{array}{l}\ddot{\varphi} \\
\ddot{n}\end{array}$ & $\begin{array}{l}\infty \\
\dot{J}\end{array}$ \\
\hline & 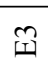 & $\vec{f}$ & $\begin{array}{l}\infty \\
\dot{f}\end{array}$ & $\begin{array}{l}0 \\
\dot{0}\end{array}$ & $\ddot{q}$ & $\vec{q}$ & $\stackrel{+}{\dot{q}}$ & $\vec{q}$ & $\begin{array}{l}0 \\
\stackrel{m}{m}\end{array}$ & $\overrightarrow{\dot{\gamma}}$ & $\ddot{q}$ & $\underset{\forall}{\stackrel{\sigma}{+}}$ & $\stackrel{\Re}{\mathcal{f}}$ \\
\hline & N & $\begin{array}{l}\infty \\
\dot{i}\end{array}$ & $\hat{\vec{d}}$ & $\hat{i}$ & $\vec{\Delta}$ & $\ddot{q}$ & $\stackrel{\sim}{a}$ & $\begin{array}{l}0 \\
\stackrel{9}{2}\end{array}$ & $\hat{\sigma}$ & $\overrightarrow{\stackrel{\sim}{~}}$ & $\stackrel{\circ}{\circ}$ & ֻุ & $\stackrel{+}{\stackrel{\sim}{~}}$ \\
\hline & 可 & $\underline{\sigma}$ & $\begin{array}{l}0 \\
0\end{array}$ & $\stackrel{\circ}{I}$ & n & $\begin{array}{l}\infty \\
\ddot{d}\end{array}$ & $\begin{array}{l}n \\
\sim\end{array}$ & $\stackrel{0}{0}$ & $\begin{array}{l}\forall \\
\stackrel{\sim}{*}\end{array}$ & $\stackrel{n}{\sim}$ & $\ddot{i}$ & $\stackrel{+}{\dot{\sim}}$ & 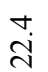 \\
\hline \multicolumn{2}{|c|}{$\underset{<}{\infty}$} & $\stackrel{+}{\sim}$ & $\begin{array}{l}8 \\
2 \\
\sim\end{array}$ & $\begin{array}{l}\mathbb{J} \\
1 \\
n \\
\checkmark\end{array}$ & $\frac{1}{6}$ & $\stackrel{+}{\sim}$ & $\begin{array}{l}\nabla \\
\sim \\
\sim\end{array}$ & $\begin{array}{l}t \\
0 \\
1 \\
f\end{array}$ & $\frac{+}{6}$ & 点 & $\begin{array}{l}\text { J } \\
2 \\
2\end{array}$ & $\begin{array}{l}\text { to } \\
\vdots \\
f\end{array}$ & $\frac{+}{6}$ \\
\hline \multicolumn{2}{|c|}{$\begin{array}{l}\dot{\bar{v}} \\
\overline{0} \\
\overrightarrow{0}\end{array}$} & \multicolumn{4}{|c|}{$\frac{\ddot{\theta}}{\sum^{\pi}}$} & \multicolumn{4}{|c|}{ 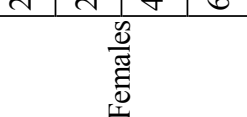 } & \multicolumn{4}{|c|}{ 氶 } \\
\hline \multicolumn{2}{|c|}{ 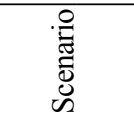 } & \multicolumn{4}{|c|}{ 峁 } & \multicolumn{5}{|c|}{ 离 } & \multicolumn{3}{|c|}{$\bar{N}$} \\
\hline
\end{tabular}


APPENDIX 2

\section{STATE ABBREVIATIONS}

\begin{tabular}{|c|l|}
\hline Code & State / Country Name \\
\hline IN & INDIA \\
\hline AP & Andhra Pradesh \\
\hline BR & Bihar \\
\hline CT & Chhattisgharh \\
\hline DL & Delhi \\
\hline GA & Goa \\
\hline GJ & Gujarat \\
\hline HP & Himachal Pradesh \\
\hline HR & Haryana \\
\hline JH & Jharkhand \\
\hline JK & Jammu \& Kashmir \\
\hline KA & Karnataka \\
\hline KL & Kerala \\
\hline MH & Maharashtra \\
\hline MP & Madhya Pradesh \\
\hline OR & Orissa \\
\hline PB & Punjab \\
\hline RJ & Rajasthan \\
\hline TN & Tamil Nadu \\
\hline UP & Uttar Pradesh \\
\hline UT & Uttaranchal \\
\hline WB & West Bengal \\
\hline B & Aggregat - North East \\
\hline AR & Arunchal Pradesh \\
\hline AS & Assam \\
\hline ML & Meghalaya \\
\hline MN & Manipur \\
\hline MZ & Mizoram \\
\hline NL & Nagaland \\
\hline SK & Sikkim \\
\hline TR & Tripura \\
\hline C & Aggregat - Small Regions \\
\hline AN & Andaman \& Nicobar Islands \\
\hline CH & Chandigarh \\
\hline DD & Daman \& Diu \\
\hline DN & Dadra \& Nagar Haveli \\
\hline LD & Lakshadweep \\
\hline PY & Pondicherry \\
\hline & \\
\hline
\end{tabular}

